\title{
Penafsiran Modern Ayat-Ayat Waris: Perbandingan Muhammad Shahrūr dan Munawir Sjadzali
}

\author{
Muhammad Iqbal Piliang, M. Najib Tsauri \\ UIN Syarif Hidayatullah Jakarta \\ muhammadiqbalpiliang5@gmail.com,m.najib_tsauri@uinjkt.ac.id
}

Abstract: This paper discusses inheritance discourse based on verses of the Qur'an according to modern interpreters, Muhammad Shahrür with Munawir Sjadzali. Both interpreters are appointed because they can be considered to have tried in their respective contexts to answer the emergence of ambiguous attitudes in implementing inheritance law from Muslim societies. Muhammad Shahrür understands and applies it in a way that is different from the opinions and concepts, as seen in the 'four classical patterns of calculation' (al-amalìyāt al-arba 'fì al-hisäb) as well as in social aspects, such as the concept of patrilinialism in society and the spirit of kinship and family spirit and ethnicity which became the benchmark for the distribution of inheritance in the past century or in political aspects, such as overlapping concepts of inheritance law which confuse ownership, law and prophetic authority. From this there is a clear relevance between the boundary theory proposed by Shahrür and the efforts to reform Islamic law which are expected to grow with justice and be able to answer the needs of the community. Whereas Sjadzali developed the concept of inheritance contained in the Qur'an, to look for the relevance of Islamic teachings to the times, especially in the context of Modern Indonesia. Since al-Qur'an is multidimensional, as hudan li al-nās, the concept of Sjadzali's inheritance law has its own value, namely by teaching the principle of equality as the division of men is twice as large as women is no longer relevant. He also did not explain the division of inheritors who have an upward line adequately. This is because Sjadzali only sees from the side of the historicity of the region as the birth of his 1: 1 inheritance concept, without regard to other aspects such as heirs and heirs.

Keywords: Inheritance, Figh, Contemporary, al-Qur'an.

Abstrak: Tulisan ini mendiskusikan wacana waris yang didasarkan pada ayat-ayat al-Qur'an menurut penafsir modern, Mubammad Shahrür dengan Munawir Sjadzali. Kedua penafsir ini diangkat karena keduanya dapat dianggap telah berusaha dalam konteksnya masing-masing untuk menjawab munculnya sikap ambigu dalam mengimplimentasikan hukum waris dari kalangan masyarakat muslim. Muhammad Shahrür memahami dan mengaplikasikannya dengan cara yang berbeda dengan pendapat dan konsep, seperti terlihat pada 'empat pola 
perhitungan klasik' (al-amalīyāt al-arba' fì al-hisāb) maupun pada aspek sosial, seperti konsep patrilinialisme dalam masyarakat dan semangat kekeluargaan dan kesukuan yang menjadi patokan pembagian harta warisan pada abad lalu ataupun pada aspek politik, seperti tumpangtindihnya konsep hukum waris yang mencampuradukkan antara kepemilikan, hukum dan otoritas kenabian. Dari sini ada relevansi yang cukup jelas antara teori batas yang digagas oleh Shahrür dan upaya pembaharuan hukum Islam yang diharapkan tumbuh berkembang berkeadilan, dan mampu menjawab kebutuhan masyarakat. Sedangkan Sjadzali mengembangkan konsep waris yang terdapat dalam al-Qur'an, untuk mencari relevansi ajaran Islam dengan perkembangan zaman, khususnya dalam konteks Indonesia Modern. Mengingat al-Qur'an bersifat multi-dimensional, sebagai hudan li al-nās, konsep hukum waris Sjadzali, memiliki nilai tersendiri yaitu dengan mengajarkan prinsip persamaan sebagaima pembagian laki-laki dua kali lipat lebih besar dari perempuan tidak lagi relevan. Ia juga tidak menjelaskan pembagian waris yang memiliki garis ke atas secara memadai. Hal ini karena Sjadzali hanya melihat dari sisi historisitas kedaearahan sebagai wujud kelahiran konsep pembagian waris 1:1 miliknya, tanpa memperhatikan aspek lainnya seperti Abli Waris dan Pewaris.

Kata Kunci: waris, fiqih, kontemporer, al-qur'an.

\section{Pendahuluan}

Pengertian waris menurut bahasa tidaklah terbatas hanya pada hal-hal yang berkaitan dengan harta, akan tetapi mencakup harta benda dan non harta benda. ${ }^{1}$ Kata waris dalam berbagai bentuk makna tersebut dapat kita temukan dalam al-Qur'an, yang antara lain: a) Mengandung makna "mengganti kedudukan" (QS. al-Naml [27]: 16); b) Mengandung makna "memberi atau menganugerahkan" (QS. al-Zumar [39]: 74); c) Mengandung makna "mewarisi atau menerima warisan" (QS. al-Maryam [19]: 6). ${ }^{2}$

Adapun dalam istilah umum, waris adalah perpindahan hak kebendaan dari orang yang meninggal dunia kepada ahli waris yang masih hidup. Seperti yang disampaikan oleh Wiryono Projodikoro, definisi waris adalah soal apakah dan bagaimanakah pelbagai hak-hak dan kewajiban-kewajiban tentang kekayaan seseorang pada waktu ia meninggal akan beralih kepada orang lain yang masih hidup. ${ }^{3}$

Dengan demikian, secara garis besar definisi warisan yaitu perpindahan berbagai hak dan kewajiban tentang kekayaan seseorang yang meninggal dunia 
kepada orang lain yang masih hidup dengan memenuhi syarat dan rukun dalam mewarisi.

Selain kata waris tersebut, juga ditemukan istilah lain yang berhubungan dengan warisan, diantaranya adalah: 1) Warith, adalah orang yang termasuk ahli waris yang berhak menerima warisan; 2) Muwarith, adalah orang yang diwarisi harta bendanya (orang yang meninggal) baik secara haqiqy maupun hukmy karena adanya penetapan pengadilan; 3) Al-Irthi, adalah harta warisan yang siap dibagikan kepada ahli waris yang berhak setelah diambil untuk pemeliharaan jenazah, melunasi hutang dan menunaikan wasiat; 4) Warathah, yaitu harta warisan yang telah diterima oleh ahli waris; dan 5) Tirkah, yaitu seluruh harta peninggalan orang yang meninggal dunia sebelum diambil untuk pemeliharaan jenazah, melunasi hutang, menunaikan wasiat. ${ }^{4}$

Adapun pengertian hukum kewarisan menurut Kompilasi Hukum Islam (KHI) adalah hukum yang mengatur tentang pemindahan hak pemilikan harta peninggalan (tirkah) pewaris, menentukan siapa-siapa yang berhak menjadi ahli waris dan berapa bagiannya (Pasal 171 huruf a KHI). ${ }^{5}$

Dalam fiqih mawaris ada ilmu yang digunakan untuk mengetahui tata cara pembagian dan untuk mengetahui siapa-siapa saja yang berhak mendapat bagian, siapa yang tidak mendapat bagian dan berapa besar bagiannya adalah ilmu farāiḍ.

Al-farāid (الفرائض) adalah bentuk jamak dari kata al-faridah (الفريضة) yang oleh para ulama diartikan semakna dengan lafaz mafruḍah, yaitu bagian-bagian yang telah ditentukan kadarnya. ${ }^{6}$ Diartikan demikian karena dalam hukum kewarisan Islam bagian-bagian yang telah ditentukan kadarnya tersebut dapat mengalahkan bagian-bagian yang belum ditentukan kadarnya dan bagian yang telah menjadi hak ahli waris telah dibakukan dalam al-Qur'an.

Jadi secara terminologi pengertian faräid adalah suatu cara yang digunakan untuk mengetahui siapa-siapa yang memperoleh bagian-bagian tertentu, maka ditetapkan terlebih dahulu ahli-ahli waris dari orang yang meninggal. Selanjutnya baru dapat diketahui siapa di antara ahli waris yang mendapatkan bagian dan yang tidak mendapat bagian tertentu. ${ }^{7}$

Dari pengertian waris di atas, yang menjadi penting dalam tulisan ini adalah persoalan soal waris, sering timbul menjadi salah satu persoalan krusial dan sensitif dalam sebuah keluarga. Seperti permasalahan waris yang digambarkan oleh David S. Powers dalam tesisnya, ia menjelaskan bahwa salah satu sebab perpindahan hak milik dalam pandangan hukum Islam adalah waris, yakni pemberian hak milik atas sesuatu secara suka rela oleh seseorang (al-mūsī) kepada orang lain (al-mūssā lahu), yang pelaksanaannya ditangguhkan hingga 
yang disebut pertama meninggal dunia. ${ }^{8} \mathrm{Al}$-Qur'an menggariskan dasar yang jelas mengenai anjuran berwasiat ini. Dalam QS. al-Baqarah [2]: 180, misalnya, Allah memerintahkan kepada orang-orang yang merasakan tanda-tanda akan datangnya maut dan mempunyai harta supaya berwasiat untuk ibu-bapak dan karib kerabatnya. Pada ayat yang lain Allah berfirman: "Dan orang-orang yang akan meninggal dunia di antaramu dan meninggalkan istri, hendaklah berwasiat untuk istri-istrinya, (yaitu) diberi nafkah hingga setahun lamanya" (QS. alBaqarah [2]: 240). Dalil-dalil ini menunjukkan betapa wasiat itu diperintahkan atas seseorang sebagai tindakan terakhir yang harus dilakukan sebelum meninggal, sehubungan dengan sanak keluarga dan harta yang akan ditinggalkannya. ${ }^{9}$

Dari perspektif historis, para ulama memandang ayat-ayat di atas sebagai tahapan pertama dari perhatian Islam berkaitan dengan pembagian harta pusaka, yakni dengan jalan wasiat. Oleh karena itu, ayat-ayat tersebut sering disebut juga sebagai "ayat-ayat wasiat". Dengan ketentuan ini, sipemilik harta diberi kebebasan untuk menentukan pihak-pihak mana yang akan menerima hartanya setelah dia meninggal. Tahapan berikutnya adalah turunnya ayat-ayat yang menetapkan ketentuan spesifik bagi masing-masing ahli waris. Ketentuan ini terdapat dalam QS. al-Nisā’ [4]: 11, 12, dan 176, yang kemudian dikenal sebagai "ayat-ayat waris". ${ }^{10}$ Ketentuan dalam ayat-ayat ini memberikan kejelasan mengenai pihak-pihak yang berhak menerima bagian dari harta pusaka orang yang meninggal dunia, sehingga pembagiannnya tidak lagi tergantung pada kehendak sipemilik harta.

Sebagian ulama menganggap bahwa ketentuan dalam "ayat-ayat wasiat" telah dihapus (mansükh) oleh ketentuan dalam "ayat-ayat waris" yang turun kemudian. ${ }^{11}$ Namun, terlepas dari benar-tidaknya anggapan itu, diakui bahwa al-Qur'an sendiri dengan jelas masih mengindikasikan validitas wasiat, karena bagian-bagian ahli waris yang sudah tertentu (al-furüd al-muqaddarah) hanya dianggap berlaku untuk sisa harta "setelah menunaikan wasiat dan pembayaran utang" (mim ba'di wasiyyatiy yūsā bihā au dainin). ${ }^{12}$ Dengan kenyataan tersebut, dapat disimpulkan bahwa al-Qur'an mengakui adanya dua sistem pembagian pusaka; dengan jalan wasiat dan dengan jalan mengikuti bagian-bagian yang sudah spesifik. Persoalannya yang kemudian adalah bagaimana menyikapi dua sistem pembagian kekayaan yang sama-sama diakui oleh al-Qur'an tersebut. Pertanyaan ini perlu mendapat jawaban mengingat bila keduanya dilaksanakan secara bersamaan, maka akan ada pihak-pihak, seperti ibu dan bapak, yang mendapat bagian secara dua kali. ${ }^{13}$ 
Masalah lain, bahwa kewarisan bagi umat Islam, misalnya di Indonesia penyelesaiannya menjadi wewenang Pengadilan Agama. Tentang hukum yang digunakan dalam menyelesaikan kewarisan itu adalah hukum Islam tentang kewarisan. Hakim dalam memutus perkara merujuk pada kitab-kitab fikih, khususunya fikih yang berkembang di Indonesia pada umumnya adalah mengikuti mazhab Imām al-Shāfi'î, tanpa menutup adanya aliran fikih atau mazhab lain, meskipun kecil. Karena dalam menentukan hukum, hakim dalam memutuskan yang merujuk kepada fikih menghasilkan penetapan yang berbeda-beda dalam suatu kasus kewarisan, baru menimbulkan masalah. Hal ini mendorong pemuka negara untuk merumuskannya dalam satu bentuk kesatuan, setelah melalui proses panjang. Mahkamah Agung sebagai pemegang kekuasaan peradilan di Indonesia bersama Menteri Agama, dengan melibatkan ulama, para pakar fikih, berhasil mengeluarkan Kompilasi Hukum Islam Indonesia. ${ }^{14}$

Seiring tumbuhnya kesadaran dan semangat untuk selaras dengan ajaran agama dalam al-Qur'an di kalangan umat Islam, maka masalah kewarisan ini menjadi yang ambigu dan memprihatinkan dengan munculnya sikap mendua dalam beragama. Di satu sisi, masyarakat masih menganggap adanya relevansi segala ketentuan hukum tekstual yang terdapat dalam al-Qur'an. ${ }^{15}$ Di sisi lain, mereka meminta dan menjalankan fatwa baru yang dianggap "lebih adil" dalam hal pembagian, atau mereka melakukan tindakan preventif dengan membagi harta peninggalan (warisan) keluarga dengan model hibah sebelum orang tua (pewaris) meninggal. ${ }^{16}$

Maka dari itu, untuk menjelaskan permasalahan waris, penulis merasa perlu untuk melakukan kajian komparatif terhadap penafsiran Muhammad Shahrūr dan Munawir Sjadzali. Keduanya memiliki latar belakang yang berbeda. Tokoh yang pertama pemikir liberal kontrovesial dari Syiria yang dijuluki sebagai "Immanuel Kant"-nya dunia Arab dan "Martin Luther"-nya dunia Islam. Ia dengan keras dan tajam mengkritik konservatisme pemikiran Islam dan berusaha mendekontruksi hegemoni pemikiran klasik yang masih tertanam kuat dalam pengetahuan dan kesadaran umat Islam. Dengan lantang ia menyerukan kepada segenap umat Islam untuk "membedah" pemikiran kesilaman selama ini sampai ke akar-akarnya yang paling dalam, yakni sistem pemikiran (episteme) yang dianut oleh umat Islam hingga sekarang ini. ${ }^{17}$ Sedangkan yang kedua adalah seorang negarawan dan ilmuan dari Indonesia. Ia pernah melontarkan isu tentang reaktulisasi ajaran Islam yang berkaitan dengan gugatan yang cukup fundamental pada nașs-nașs syari'ah. Pada saat itulah ia mulai memasuki persoalan dilematis antara syari'ah yang bersifat holistik dan 
realitas keindonesiaan yang bersifat domestik. Namun di luar dari pengemukaan ide tersebut, ia telah mencoba membangun karakter baru syari'ah yang dalam lontaran politik dikenal dengan istilah "membangun peradaban dan karakter masyarakat yang khas Indonesia (nation state and character building) yang pluralistik dan anti diskriminasi berdasarkan apapun". ${ }^{18}$

Bagi Muhammad Shahrūr, ayat-ayat waris adalah termasuk ayat-ayat hudüdiyah yang memiliki batas maksimal dan minimal. Hal ini diambil dari potongan ayat (ويتعد حدوده) (تلك حدوداله). petunjuk bahwa boleh bergerak antara kedua batas maksimal dan minimal, dan bukan semata-mata berhenti pada batas. Bahwa Allah-lah yang berhak menentukan batas, sedangkan Nabi saw hanyalah berijtihad untuk menerapkan hal yang sesuai dengan kondisi yang melingkupinya selama masih dalam batasbatas yang ditetapkan oleh Allah. Maka dari itu untuk mengatasi problem epistemologis, Shahrūr menawarkan metode baru dalam hal penafsiran ayatayat waris, yakni dengan menerapkan ilmu eksakta modern, yakni matematika analitik, tehnik analitik dan teori himpunan, di samping matematika klasik masih tetap digunakan. ${ }^{21}$

Berbeda dari pengamatan Sjadzali soal waris, ia bisa menerima ketentuan al-Qur'an yang mengatakan bahwa laki-laki mendapat bagian dua kali lebih besar dari perempuan dalam pembagian harta waris, jika memang ketentuan ini membawa implikasi tanggungjawab penuh (untuk membayar mas kawin atau mahar, nafkah, dan perumahan) dari pihak laki-laki sebagai suami. Persoalannya, bukankah tradisi di Indonesia tidak demikian? Dalam amatan Sjadzali, tradisi mahar di Indonesia sekarang ini tinggal formalitas semata. Selain itu, istri dan suami sama-sama mencari nafkah untuk memenuhi kebutuhan hidup keluarganya. Dengan demikian, maka hubungan antara suami dan istri tidak lagi merupakan hubungan antara yang memberi dan yang menerima, akan tetapi hubungan dua anak manusia yang sepakat untuk hidup bersama dan membina keluarga atas dasar gotong royong, masing-masing bekerja mencari nafkah untuk tegaknya rumah tangga. Atas dasar pengamatan empiris ini, Sjadzali berpendapat bahwa pembagian laki-laki dua kali lebih besar dari perempuan tidak lagi relevan. ${ }^{22}$

Maka dari itu, pentingnya penafsiran modern dari kedua tokoh tersebut yakni untuk mengadaptasikan teks al-Qur'an dengan situasi kontemporer seorang mufassir atau menyesuaikan ayat-ayat al-Qur'an dengan tuntunan zaman (pendekatan yang sesuai dengan problem yang sedang dihadapinya atau yang melatarbelakinya). Dari perbedaan latar belakang dan metodologi yang digunakan oleh Muhammad Shahrūr dan Munawir Sjadzali, dapat membantu 
menjelaskan persoalan waris dari sudut pandang yang beragam sehingga persoalan utama yang melatarbelakangi penelitian ini dapat dijelaskan.

Dari uraian di atas dapat terlihat jelas perbedaan para sarjana-sarjana dari berbagai disiplin ilmu. Hal inilah yang mendasari ketertarikan penulis untuk menelusuri lebih jauh penafsiran Muhammad Shạ̣rūr dan Munawir Sjadzali terhadap ayat-ayat waris yang berimpliksi terhadap hukum Islam dan penerapannya dalam masyarakat. Adapun pertimbangan penulis menjadikan pemikiran Muḥammad Shaḥrūr dan Munawir Sjadzali sebagai objek penelitian didasari pandangan penulis di mana Shahrūr mempunyai pengaruh kuat akibat metodologi yang dikembangkannya dengan segala kontroversinya dan Sjadzali mempunyai gagasan reaktualisasi dalam hukum Islam, hal ini menjadi menarik untuk diangkat dan dikaji sebagai kesinambungan proses pertumbuhan metodologi tafsir kontemporer.

Sebenarnya, apa yang menjadi problem mendasar bagi Islam menurut Shahrūr dan Sjadzali adalah umat Islam telah terjerembab pada tradisi tanpa bisa secara selektif dalam mengkritisi, dan hanya mengikuti tradisi dengan apa adanya. Tetapi pada sisi yang lain, umat Islam meninggalkan sama sekali tradisi dan berlari pada tradisi pada peradaban lain (tradisi Barat). Padahal yang seharusnya dilakukan umat Islam adalah membaca kembali al-Qur'an sebagai rujukan bagi perkembangan Islam, karena dari situ, pengaran kebudayaan Islam akan menjadi kuat.

Penulis melacak ayat tentang waris dalam al-Qur'an terdapat beberapa surat dan ayat antara lain QS. al-Baqarah [2]: 180-182 dan 240; QS. al-Nisā' [4]: 7, 8, 11, 12, 13, 33, dan 176; QS. al-Mā'idah [5]: 106-107. Hanya saja Munawir Sjadzali tidak semua ayat yang penulis sebutkan ia tafsirkan. Baik Shahrūr ataupun Sjadzali, penulis hanya berkutat pada konsep pembagian waris menurut keduanya.

Adapun alasan penulis mengupas bahasan ini karena tergolong perkara yang rumit dan banyak timbul permasalahan dalam keluarga soal urusan warismewaris. Oleh sebab itu, pembahasan mengacu penafsiran Muhammad Shaḥūur dan Munawir Sjadzali terhadap ayat-ayat waris dalam al-Qur'an, serta relevansi penafsiran keduanya pada konteks waris di Indonesia.

\section{Biografi Muhammad Shaḥrūr dan Munawir Sjadzali}

1. Muhammad Shahrūr.

Shaḥūr, --tokoh yang pernah membuat gempar dalam pemikiran Islam-- bernama lengkap Muhammad Shahrūr bin Daib Tahir dilahirkan di perempatan Sahiliyah Damaskus, Syiria, pada tanggal 11 April 1938 M ketika 
negeri tersebut masih dijajah oleh Perancis walaupun sudah mendapatkan status separuh merdeka. Shahrūr adalah anak kelima dari seorang tukang celup. ${ }^{23}$ Ayahnya bernama Deyb bin Deyb Shahrūr dan ibunya adalah Siddiqah binti Salih Filyun. Shahrūr menjatuhkan hatinya kepada Azizah yang sekarang menjadi istrinya. Ia dikaruniai lima anak dan dua cucu. Ketiga anaknya sudah menikah yaitu Tariq (beristrikan Rihab), Lays (beristrikan Olga), dan Rima (bersuamikan Luis). Sedangkan kedua anak lainnya adalah Basil dan Mas'un dan dua cucunya bernama Muhammad dan Kinan. ${ }^{24}$

Shậūr memulai perjalanan intelektualnya dari sekolah tempat kelahirannya, yaitu diawali di sekolah ibtida'iyyah dan thanāwiyyah (lulus tahun 1957) di lembaga pendidikan 'Abd al-Raḥman al-Kawākibī di al-Midan di pinggiran kota sebelah selatan Damaskus yang berada di luar batas dinding kota tua. Karirnya dikemudian hari sangat bertipe kaum intelektual pasca kemerdekaan dari negeri bekas koloni Eropa. ${ }^{25}$ Shahrūr mendapat beasiswa pemerintah studi teknik sipil (handasah madaniyah) pada Maret 1957. Ia dikirim ke Saratow, dekat Moskow, Uni Soviet (sekarang Rusia), dan berhasil meraih gelar Diploma pada tahun 1964. Kemudian pada tahun berikutnya, dia mengajar pada Fakultas Teknik Sipil Universitas Damaskus. ${ }^{26}$

Belum lama mengajar di Fakultas Teknik Sipil Universitas Damaskus (kurang lebih tiga tahun), pada tahun 1968 ia dikirim untuk belajar keluar negeri oleh universitasnya ke Irlandia, tepatnya Ireland National University ( $A l$ Jami'ah Al-Qaumiyah Al-Irlandiyyah) untuk memperoleh gelar Magister (MA) pada tahun 1969 dan gelar doctoral (Ph.D) dalam bidang spesialisasi Mekanika Pertanahan dan Pondasi (Mekanika Turbat wa Asäsat) di Universitas College Dublin Irlandia, dan diselesaikannya tahun 1972. Pada tahun itu juga ia memulai kiprah intelektualnya sebagai seorang professor dan diangkat secara resmi menjadi dosen fakultas Teknik Sipil Universitas Damaskus dengan mengampu mata kuliah Mekanika Pertanahan dan Geologi (Mekanika alTurbat wa al-Manshäat al-'Ardiyyah) hingga sekarang. ${ }^{27}$

Saat Shahrūr menempuh studi di Universitas Nasional Irlandia, Dublin, inilah periode pertama (1970-1980) untuk menelurkan karya monumental Shahrūr, al-Qur'ān Wa al-Kitäb, Qira'ah Mu'asirah yang merupakan hasil perjalanan panjang sekitar 20 tahun. Pada periode ini adalah tahap pengujian kembali dan peletakan dasar-dasar metodologi pemahaman terhadap konsep alDhikr, al-Risālah dan Nubuwwah serta penetapan-penetapan istilah dasar bagi al-Dhikr. Pada tahap ini diakuinya merupakan tahap yang tidak produktif karena hanya menghasilkan berbagai asumsi tentang konsep al-Dhikr yang tidak saling terkait dan lemah. ${ }^{28}$ 
Adapun yang menjadi sebab utama pada kondisi ini adalah pengaruh warisan literatur Islam berupa madzhab fiqh (fiqh lima madzhab) dan aliran teologi tertentu baik Ash'ariyah maupun Mu'tazilah, baik pada zaman klasik maupun sekarang. Di samping itu, juga pengaruh berbagai asumsi sosiologis yang dianggap Shaḥūr sebagai postulat kebenaran. Hal ini membuat Shaḥūur terdampar pada studi ilmiah yang statis dan beku. ${ }^{29}$

Adapun karya-karya Shaḥūr terbagi dalam beberapa kategori: 1) Bidang Teknik; Handasat al-Asāsat (ilmu pondasi) 4 jilid dan Handasat al-Turāb (ilmu tanah). Kedua karya tersebut merupakan buah karya ketika Shahrūr menempuh pendidikan Magister dan Doktoral di Universitas College Dublin Irlandia. 2) Bidang Keislaman; Al-Kitāb wa al-Qur'ān: Qirā'ah Mua'shirah (1990), Dirāsat al-Islāmiyyah al-Mu'shirah fì Dawlah wa al-Mujtama'ah (1994), Al-Islàm wa al-Imān: Manzumah al-Qiyām (1996), Mashrū'Misāq al-Āmal al-Islāmī (1999), Naḥw Ușūl Jadìdah Li al-Fiqh al-Islāmī: Fiqh al-Mar'ah (2000). Selain menulis buku, Shahrūr juga aktif menulis berbagai artikel ilmiah di beberapa media. ${ }^{30}$

\section{Munawir Sjadzali}

Munawir Sjadzali dilahirkan pada 7 Nopember 1925 di desa Perdikan Kesunanan Surakarta bernama Karanganom, jaraknya sekitar 8 kilometer dari ibukota Daerah Tingkat II Klaten, Jawa tengah, Indonesia. Ia dibesarkan dari keluarga dengan tradisi keagamaan mazhab Sunni yang kental. ${ }^{31}$ Munawir Sjadzali adalah anak tertua dari delapan orang bersaudara dari pasangan Abu Aswad Hasan Sjadzali (putra Tohari) dan Tas'iyah (putri Badruddin). Setelah menikah, kedua orang tua Sjadzali mendapat nama tua Mughaffir. ${ }^{32}$ Keluarga Mughaffir dari segi ekonomi jauh dari sejahtera, tetapi dari segi agama --dengan meminjam terminologi Clifford Geertz-- keluarga ini adalah termasuk santri. ${ }^{33}$ Bukti kesantriannya dapat dicirikan dari pengembaraannya mencari ilmu (riḅlah ilmiyah) ke berbagai daerah. Mughaffir pernah tercatat sebagai santri di sejumlah pesantren tradisional yang terkenal saat itu, antara lain Pesantren Jamsaren (Solo Jawa Tengah), Pesantren Tebuireng (Jombang Jawa Timur), dan Pesantren Termas (Pacitan Jawa Timur). Ia juga Aktif di organisasi Muhammadiyah sehingga pernah menduduki jabatan Ketua Ranting Muhammadiyah di kampungnya. Di samping itu, Mughaffir adalah penganut tarekat Sjadzaliyah yang merupakan salah satu ordo mistik dalam mistisisme Islam.

Latar belakang kesantrian Mughaffir tidak hanya sebagai kepala keluarga yang menghiasi rumah tangganya dengan nilai-nilai religius, tetapi juga menjadikannya orang yang memiliki pengetahuan agama yang cukup luas. 
Karena itu pula dilingkungan masyarakat Karanganom ia dikenal dengan sebagai Kiyai, suatu sebutan yang dipandang ahli dalam ilmu-ilmu keagamaan Islam, juga sekaligus pemimpin informal masyarakat. ${ }^{34}$

Sjadzali kecil menerima pendidikan dari ayahnya sendiri, Abu Aswad Hasan Sjadzili, kemudian dari Pondok Pesantren dan Madrasah seperti; Madrasah Ibtidaiyah, Sekolah Rakyat, Madrasah al-Islam dan Madrasah Mambaul Ulum yang berada di Solo. ${ }^{35}$ Ketika itulah ia mulai belajar bahasa Arab (Nahwwu ['Amrịtī, Mutammimah, Alfiyah Ibnu Mālik], Șaraf, Bayān, Ma'ānī, Badī', dan Arūud), teologi, hadis, tafsir (al-Jalālain), Fikih (Fath alQarīb, safinah al-najāh, Fath al-Mu'ìn, Fath al-Wahhāb, al-Muhadzab), Ushul Fiqh (Irshäd al-Fuhül, Waraqāt), falak, balaghah, bahasa dan ilmu hitung. ${ }^{36}$ Intelektualitas Sjadzali semakin teguh dengan penguasaan dalam berbagai bahasa: Jawa, Melayu, Arab, Inggris dan Prancis.

Tahun 1943, di usia 17 tahun, Sjadzali menamatkan sekolahnya di Mambaul Ulum. Ia juga menyandang predikat sebagai lulusan terbaik dari Madrasah tersebut. ${ }^{37}$ Setelah lulus Sjadzali bercita-cita sekolah di Universitas alAzhar, Kairo, Mesir, namun hal itu tidak kesampaian karena ayahnya tidak mampu membiayai. Batal melanjutkan sekolah, maka rencana Sjadzali adalah bekerja. Sambil mengembara sampailah ia di Salatiga di mana ia mendengar sekolah Muhammadiyah setempat membutuhkan seorang guru. Kemudian setelah lamarannya diterima ia menjadi guru Sekolah Rakyat Muhammadiyah dengan masa percobaan. Karena statusnya percobaan, ia melamar dan diterima sebagai guru tetap di Madrasah Ibtidaiyah di Gunungpati Ungaran. ${ }^{38}$

Dari Gunungpati inilah keterlibatan Sjazali dengan kegiatan-kegiatan umat Islam dalam skala nasional dimulai. Bermula dari sedikitnya kaum terpelajar di tempat ini, kegiatannya yang tadinya hanya mengajar berkembang ke arah kegiatan-kegiatan yang bersifat sosial. Sjazali selalu dilibatkan dalam pembentukan badan-badan semi-resmi maupun swasta. Sampai akhirnya untuk pertama kalinya Sjazali bertemu dan berdialog dengan Bung Karno yang waktu itu menjabat sebagai ketua umum Putera (Pusat Tenaga Rakyat). Ia juga menjalin hubungan baik dengan kepala Kantor Urusan Agama Karesidenan Semarang, KH. Munawar Cholil salah seorang ulama produktif dalam menulis dan mempunyai visi kembali pada pemahaman yang langsung kepada al-Qur'an dan Sunnah, dan tidak mengikatkan diri pada suatu mazhab dalam fikih. ${ }^{39}$ Pada saat mengenal KH. Munawar Chalil inilah keinginan Sjazali untuk sekolah lagi di Sekolah Tinggi Islam di Jakarta timbul, namun akhirnya tidak kesampaian juga karena masalah biaya dan ijazah Mambaul Ulumnya. ${ }^{40}$ 
Pasca Proklamasi kemerdekaan RI 1945, masyarakat Gunungpati dalam rangka membantu tugas-tugas pemerintah setempat membentuk Angkatan Muda Gunungpati dengan diketuai oleh Sjazali. Organisasi ini yang kemudian membawanya bergabung dengan kelompok pejuang Islam yang dikenal dengan pasukan Hizbullah. Ia sempat menjadi salah satu pemimpin Markas Pimpinan Pertempuran Hizbullah-Sabilillah (MPHS) yang berfungsi sebagai forum komunikasi dan kordinasi untuk wilayah Jawa Timur, Jawa Tengah, dan Jawa Barat bersama KH. Wahib Wahab dan Kamran. ${ }^{41}$

Pada awal Mei 1947 keluar dekrit presiden tentang peleburan semua badan kelaskaran, termasuk Hizbullah dan Sabilillah, ke dalam Tentara Nasional Indonesia (TNI). Karena sadar tidak memiliki bakat di dunia militer, Sjazali tidak ikut meleburkan diri ke dalam TNI. Ia memilih kembali ke Solo dan aktif lagi di Gerakan Pemuda Islam Indonesia (GPII). Ketika tentara Belanda menduduki Solo dalam Aksi Militer II, Sjazali kembali aktif di dunia militer dan bergabung dengan kesatuan-kesatuan yang memilih tetap beroperasi di daerah pendudukan. Selama Aksi Militer II inilah Sjazali sempat kursus bahasa Inggris selama enam bulan.

Pada akhir 1949 dengan usainya perang kemerdekaan dan terlaksananya Konferensi Meja Bundar di Den Haag, Sjadzali kembali ke Semarang dan menetap di rumahnya KH. Munawar Cholil selama satu tahun. Di Semarang inipun Sjadzali sempat mengikuti kursus privat bahasa Prancis. Di samping itu selama di Semarang Munawir juga menemukan jodohnya dengan seorang gadis yang bernama Murni, aktifis Pelajar Islam Indonesia (PII), putri dari Tas Sekti, cucu Tasripin yang semasa hidupnya merupakan "konglomerat" pribumi di Semarang. Mereka menikah pada 11 Oktober 1950 dan dikaruniai enam orang anak, tiga laki-laki dan tiga perempuan yaitu Muchlis (almarhum), Mustahdiyati, Mustain, Muhtadi, Mutiawati dan Muflihatun. Mereka juga dikarunia cucu sebanyak empat belas orang. Di Semarang pula seusai Muktamar GPII Munawir mencoba menelaah konsepsi politik Islam yang berkembang di masa klasik. Hal ini didorong oleh demikian kuatnya aspirasi Islam sebagai dasar Negara yang muncul dikalangan aktifis dan pemikir Islam terutama tokoh Masyumi. Dengan memanfaatkan perpustakaan KH. Munawar Cholil, yang penuh kitab-kitab klasik, Sjadzali berhasil menulis buku "Mungkinkan Negara Indonesia Bersendikan Islam?". Buku inilah yang selanjutnya mengantarkan Sjadzali bekerja di Kementerian Luar Negeri atas jasa Bung Hatta. ${ }^{42}$

Ketika masuk di Kementeriaan Luar Negeri, Sjadzali ditempatkan di Seksi Arab dengan tugas membaca surat kabar harian dan majalah berbahasa 
Arab kiriman dari sejumlah Kedutaan Besar RI di Negara-negara Arab. Berdasarkan bahan bacaan ini Sjadzali menulis resume untuk selanjutnya dilaporkan kepada Direktorat Politik. ${ }^{43}$ Ketekunan dan kemampuannya dalam melaksanakan tugas terus membawa karirnya semakin menanjak.

Pada akhir Agustus 1953 Sjadzali berangkat ke Inggris dengan meninggalkan istri dan kedua anaknya di Semarang untuk belajar ilmu politik di University College of South West of England, Exeter. Pada bulan Juli 1954 Sjadzali berhasil menyelesaikan studinya dan kembali ke Indonesia. Mula-mula ia ditempatkan di Direktorat Eropa, namun pada awal 1955 ia ditarik ke Sekretariat Bersama Konferensi Asia Afrika dan terlibat penuh dalam urusan kesekretariatan konferensi. ${ }^{44}$

Karir Sjadzali semakin berkembang ketika ia ditugaskan untuk menempati pos-pos barunya di luar negeri dan dalam menjalankan tugasnya ia berpindah dari satu negara ke negara lain. Pada Desember 1955, ia ditugaskan di Kedutaan Besar RI Washington DC dan diperbantukan di Atase Penerangan untuk selanjutnya dipindahkan ke bagian politik. Agustus 1956, Sjadzali mendaftarkan diri di Universitas Georgetown dan diterima langsung di Fakultas pascasarjana untuk Master of Art (MA) dengan major subject Hubungan Internasional dan minor subject filsafat politik. Hal ini karena Kursus Diplomatik dan Konsuler serta satu tahun di University College of South West of England, Exeter, dinilai sebagai sedikit di bawah gelar Bachelor of Arts (BA).

Pada tahun 1959, Sjadzali menyelesaikan kuliahnya dengan tesis berjudul "Indonesia's Muslim Political Parties and Their Political Concepts." Dengan tesis ini Sjadzali bukan hanya meraih gelar MA, tetapi juga memenuhi obsesinya untuk mencari konsepsi politik Islam. Setelah meraih MA, Sjadzali menekuni kembali karirnya di Kementerian Luar Negeri. Berkaitan dengan ini, ada dua peristiwa penting yang sangat mempengaruhi karirnya. ${ }^{45}$

Pada 1980, Sjadzali dipanggil pulang ke tanah air untuk membantu merumuskan politik Indonesia di Timur Tengah setelah terjadi kesepakatan damai antara Mesir dan Israel. Ketika tiba di tanah air Sjadzali diangkat sebagai Direktur Jenderal Politik Deplu menggantikan Chaidir Anwar Sani. Dalam posisi inilah Sjadzali sering mewakili Menlu -ketika yang bersangkutan sedang di luar negeri untuk menghadiri rapat polkam tingkat menteri. Inilah yang selanjutnya mengantarkan Sjadzali ke kursi Menteri Agama- setelah 33 tahun (1950-1983) mengembangkan karir di lingkungan departemen Luar Negeri. Sjadzali adalah merupakan satu-satunya orang yang mendapat kepercayaan dari Presiden Soeharto untuk menjabat sebagai Menteri Agama selama dua periode sejak pemerintahan Orde Baru berdiri tahun $1966 .{ }^{46}$ 
Munawir Sjadzali adalah Menteri Agama ketiga pada masa pemerintahan Orde Baru. Dua Menteri Agama pendahulunya adalah Dr. A. Mukti Ali (1972-1977) dan Alamsjah Ratu Perwiranegara (1977-1983). Mukti Ali, yang mendalami ilmu perbandingan agama, dapat dipandang sebagai penganjur dan peletak dasar bagi terbinanya kerukunan hidup antar umat beragama. Mukti Ali tampil dengan tema gagasannya "setuju dalam perbedaan" (agreement in disagreement) dalam upayanya untuk memelihara toleransi antar umat beragama. Upaya-upaya Mukti Ali kemudian dilanjutkan oleh Alamsjah Ratu Perwiranegara yang menggagas perlunya diciptakan trilogi kerukunan, yaitu kerukunan umat beragama dengan pemerintah, kerukunan antar umat beragama, dan kerukunan intern antar pemeluk suatu agama. Pada batas tertentu, Alamsjah juga berhasil memantapkan pemahaman umat Islam tentang hubungan Pancasila dan Islam. ${ }^{47}$ Namun, pada masa Sjadzali-lah pemahaman hubungan Pancasila dan Islam semakin mantap dengan diterimanya asas tunggal Pancasila sebagai satu-satunya asas organisasi secara bulat, baik oleh organisasi politik maupun organisasi kemasyarakatan. Selama menjabat sebagai Menteri Agama, gagasan yang ditawarkan oleh Sjadzali dikenal dengan "Reaktualisasi Ajaran Islam".

Sebagai cendekiawan, ada tiga kemungkinan peranan Sjadzali. Pertama, sikap kritis terhadap kondisi sekelilingnya, dan terutama terhadap kekuasaan yang korup. Kedua, memberikan legitimasi, umumnya berkaitan dengan kekuasaan atau kebijakan yang menyangkut persetujuan rakyat yang diperintah. Ketiga, melakukan rekayasa sosial yang mengarah kepada perubahan dan kemajuan. ${ }^{48}$

Selama menjabat menteri agama banyak hal yang telah dilakukan Sjadzali. Setidak-tidaknya ada tiga agenda yang menonjol, dan berkaitan dengan persoalan umat Islam Indonesia. Pertama, menuntaskan Pancasila sebagai asas organisasi sosial kemasyarakatan. Kedua, pembenahan lembaga-lembaga pendidikan Islam. Ketiga, penguatan keberadaan Pengadilan Agama dan Kompilasi Hukum Islam.

Adapun karya-karya yang dihasilkannya, tidak akan diungkap dan dijelaskan semua. Pembahasan hanya akan ditekankan kepada beberapa karyanya yang dianggap mewakili gagasan sentralnya. Di antaranya adalah; Mungkinkah Negara Indonesia Bersendikan Islam?, Reaktualisasi Ajaran Islam, Ijtihad dan Kemaslahatan Umat, Islam dan Tata Negara: Ajaran, Sejarah dan Pemikiran, Islam Realitas Baru dan Orientasi Masa Depan Bangsa, Bunga Rampai Wawasan Islam Dewasa Ini, dan Ijtihad Kemanusiaan. ${ }^{49}$ 


\section{Waris dalam al-Qur'an}

Kata waris berasal dari bahasa Arab yang diambil dari kata "waristha"

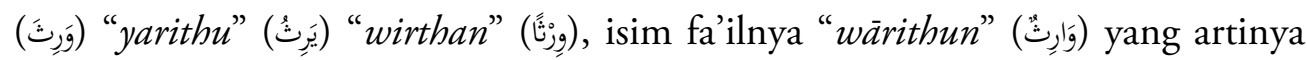
ahli waris. ${ }^{50}$ Sesuatu dari seseorang kepada orang lain atau dari suatu kaum kepada kaum lain disebut al-mirath. ${ }^{51}$ Makna al-mirath sendiri menurut istilah yang dikenal para ulama ialah berpindahnya hak kepemilikan dari orang yang meninggal kepada ahli warisnya yang masih hidup, baik yang ditinggalkan itu berupa harta (uang), tanah atau apa saja yang berupa hak milik legal menurut syari'i. Permasalahan di atas bisa disebut dengan istilah wasiat. ${ }^{52}$ Sedangkan farāid bentuk jamak dari farịdah, berarti farāid berasal dari kata "farada" (فَرَضَ)

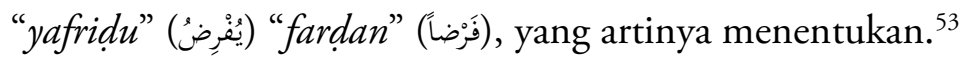

Dalam literatur hukum Islam ditemui beberapa istilah untuk menamakan kewarisan hukum Islam, seperti faräid, fikih mawaris, dan hukm al-warith. Kata yang lazim farāid, kata ini digunakan oleh al-Nawāwī dalam kitab fikih Minhaj al-Ṭalibin, oleh al-Mahallì dalam komentarnya atas matan minhaj, disebutkan alasan penggunanya dikarenakan lebih banyak terdapat bagian yang ditentukan, oleh karena itu, hukum ini dinamakan faräid. ${ }^{54}$ Sedangkan hukum kewarisan menurut fiqh mawaris adalah fiqih yang berkaitan dengan pembagian harta warisan, mengetahui perhitungan agar sampai kepada mengetahui bagian harta warisan dan bagian-bagian yang wajib diterima dari harta peninggalan untuk setiap yang berhak menerimanya. ${ }^{55}$

Waris dalam bahasa Indonesia disebut pusaka, yaitu harta benda dan hak yang ditinggalkan oleh orang yang mati untuk dibagikan kepada yang berhak menerimanya. Pembagian itu lazim disebut faräid, artinya menurut syara' ialah pembagian pusaka bagi yang berhak menerimanya. ${ }^{56}$

Al-Qurțubī menjelaskan bentuk jamak dari kata "الوصايا" "adalah" seperti halya bentuk jamak dari kata "القضاية" adalah "لقضايا". Kata digunakan untuk orang yang berwasiat dan untuk orang yang menerima wasiat. Sedangkan kata bendannya adalah "لوِصَاية" (dengan menggunakan harakat kasrah pada huruf wauw) atau bisa juga "لأوَصَاية" (dengan menggunakan harakat fathah pada huruf wauw)..$^{57}$ Sedangkan makna dari kata "تواصوا" adalah saling berwasiat di antara manusia. Seperti yang tercantum dalam hadis Nabi saw,

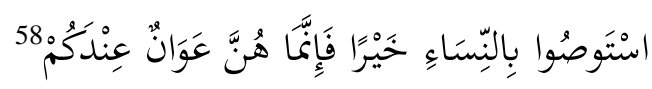

"saling berwasiatlah kepada istri-istri dengan baik, karena istri kalian adalah laksana yang ada padamu." 
Berkenaan dengan hal ini, Abū Bakr al-Jașsāạs (w. 370 H.), ${ }^{59}$ mengutip dua pendapat yang berbeda dari Ibn Abbās. Pertama, kewajiban berwasiat sebagaimana yang terdapat dalam surat al-Baqarah ayat 180. Tentang kedudukan ayat ini masih muḥkam atau mansūkh, al-Jașsāṣ menjelaskan bahwa Allah telah mewajibkan pembagian warisan dan hal itu tidak mesti me-nasakhkan kewajiban berwasiat disebabkan antara ayat-ayat tersebut ada kemungkinan (ihtimal) untuk digabungkan. Allah telah menurunkan ayat tentang kewajiban berwasiat lebih dahulu dari pada ayat-ayat tentang kewarisan. Oleh karena itu tidak ada larangan untuk mengeluarkan wasiat lebih dahulu dari warisan seperti disebutkan dalam QS. al-Nisā’ [4]: 11 dan $12 .{ }^{60}$

Ibn Kathīr (w. 774 H.), menyatakan bahwa QS. al-Baqarah [2]: 180 mengandung perintah wajib berwasiat sebelum turunnya ayat-ayat tentang kewarisan. Setelah turunnya ayat-ayat tentang kewarisan yang menetapkan pembagian warisan secara rinci, maka kewajiban berwasiat dihapuskan khususnya terhadap orang tua dan karib kerabat yang mendapat warisan. Lebih lanjut, ia menegaskan bahwa ayat-ayat kewarisan tidak me-nasakh hukum berwasiat secara keseluruhan, tetapi hanya mengangkatkan sebagian afrad (materi) kewajiban wasiat yang bersifat umum. Oleh karena itu, ayat-ayat kewarisan hanya mengangkat hukum wasiat terhadap orang-orang yang mendapat warisan saja. ${ }^{61}$

Ibn al-'Arābī ${ }^{62}$ (467H.-543H.) dalam menanggapi perbedaan pendapat ulama tentang muhkam atau mansükh-nya surat al-Baqarah ayat 180 tersebut, menegaskan pendapatnya bahwa ayat tersebut adalah mansükh, tetapi hukumnya sunah (anjuran saja), berdasarkan zahir hadis Ibn 'Umar yang berbunyi:

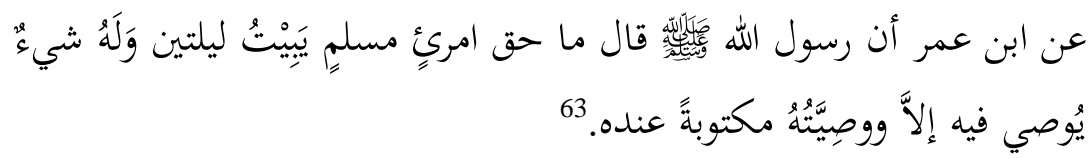

Hadis diriwayatkan dari Ibn 'Umar bahwa Rasulullah saw. telah bersabda: "Tidak berhak seorang muslim yang memiliki sesuatu yang (pantas untuk) diwasiatkan dan ia masih mempunyai kesempatan hidup selama dua malam melainkan hendaklah ia mempunyai wasiat yang ditulis".

Lafaz al-ḩaq dalam hadis Ibn 'Umar di atas, menurut Ibn al-'Arābī, berarti anjuran saja. ${ }^{64}$ Dengan demikian, Ibn al-'Arābī memandang bahwa wasiat adalah perbuatan yang tidak wajib dan hanya perbuatan baik yang dianjurkann saja. Akan tetapi Rashīd Riḍāa, ${ }^{65}$ menjelaskan bahwa QS. alBaqarah [2]: 180 adalah muḥkam, bukan mansükh. 


\section{Penafsiran Waris Menurut Muhammad Shaḥrūr dan Munawir Sjadzali}

\section{Penafsiran Muhammad Shahrūr}

Shahrūr mengawali pembahasannya yakni perintah melakukan wasiat. Ayat tersebut mewajibkan orang yang telah dekat dengan kematian dan akan meninggalkan harta (sedikit atau banyak) agar menentukan pihak-pihak yang kelak diserahi harta peninggalannya. Ayat tersebut adalah QS. al-Baqarah [2]: 180. ${ }^{66}$ Penjelasan QS. al-Baqarah [2]: 180, Shahrūr menjelaskan bahwa terdapat kesurupaan posisi seluruh manusia. Bagian yang diberikan kepada seorang pewaris dalam hukum waris ditentukan oleh posisinya dalam konstalasi pihakpihak yang menerima harta (sebagai bapak, ibu, anak, suami, istri, saudara lakilaki, ataukah saudara perempuan). Persamaan merupakan sifat yang umum, sedangkan perbedaan adalah sifat yang khusus. Waris dan wasiat menggambarkan relasi dialektis antara kesurupaan dan perbedaan. Komunitas manusia berdiri di atas keragaman kondisi penghidupan, keluarga, sosial, dan kebutuhan hidup. ${ }^{67}$

Maksudnya ayat tersebut dimulai dengan bentuk kalimat pembebanan

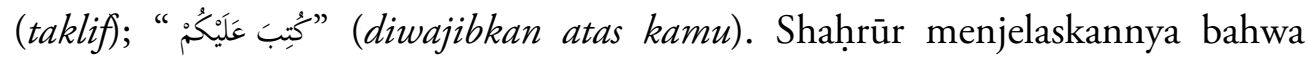
wasiat ditujukan kepada orang-orang yang bertakwa dari seluruh penduduk di

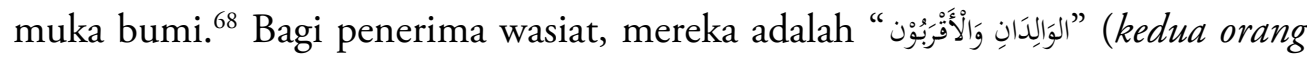
tua dan kerabat). Mayoritas orang tua terdiri dari seorang bapak dan seorang ibu. Perspektif ini menuntun untuk membedakan konsep al-wälid (bapak kandung) dan al-abb (bapak pengasuh), dan antara konsep al-wälidah (ibu kandung) dan al-umm (ibu asuh). Pembedaan ini perlu diperhatikan, khususnya ketika ayat waris menunjuk pada pengertian orang tua pengasuh, bukan orang tua kandung. Dari perbedaan ini akan tercipta koherensi antara realitas dengan maksud firman Allah. ${ }^{69}$

Menurut Shahrūr, jika orang yang hampir meninggal memberlakukan ayat ini dan mewasiatkan hartanya untuk diberikan kepada kedua orang tua

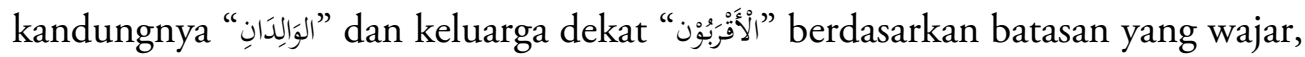
maka wasiat ini harus dilaksanakan dan tidak seorang pun mengubahnya. Larangan ini sebagaimana ditegaskan dalam QS. al-Baqarah [2]: 181.70

Jika pewasiat melakukan kesalahan, baik disengaja atau tidak, dalam membagi wasiatnya tidak sesuai dengan ketentuan al-walidani wa al-aqrabun (bagi kedua orang tua dan keluarga dekat), sementara ia masih memiliki saudara laki-laki, saudara perempuan dan anak-anak, atau melebihi batas wajar yang berlaku, seperti memberikan bagian yang lebih besar kepada paman dan bibinya 
dari pada kepada kedua orang tuannya, ${ }^{71}$ maka dalam hal ini berlaku firman Allah, QS. al-Baqarah [2]: 182.

Shahrūr menegaskan bahwa alterntif penentuan dalam pemberian wasiat terbuka luas, dan bahwa ketentuan kepada siapa wasiat diberikan sepenuhnya menjadi hak pewasiat. Dalam hal ini tidak ada batasan ataupun ketentuan yang ditetapkan oleh syariat kecuali standar ketakwaan dan rasa takut kepada Allah. Hal ini bisa saja pewasiat bisa memberikan bagian yang lebih besar kepada anaknya yang cacat daripada kepada anaknya yang sehat. Wasiat juga dapat menjangkau hal-hal yang tidak dapat dijangkau oleh ketentuan pembagian warisan. Pemahaman ini Shahrūr berpegang pada QS. al-Baqarah [2]: 240, seakan-akan Allah hendak memberikan jalan kemudahan kepada siapa saja untuk mengaplikasikan perintah memberikan keleluasaan untuk merambah wilayah lain yang dikehendaki. ${ }^{72}$

Shaḥūr melihat bahwa ayat-ayat waris dimulai dengan surat al-Nisā'

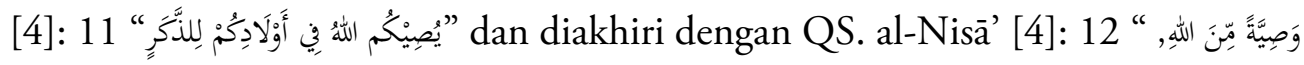
"وَاللهُ عَلِيْيُ حَليم: Selain itu Allah juga berfirman tentang wasiat kepada kita dalam QS. al-Baqarah: 180 dengan pola kalimat yang sama sebagaimana Allah menetapkan kewajiban shalat, puasa dan perang kepada kita yaitu dengan redaksi (kutiba alaikum). Shaḥūr juga memaparkan pernyataan bagaimana fiqih dapat diterapkan dalam kehidupan sehari-hari yang di antaranya adalah sebagai berikut: ${ }^{73}$

1. Mengutamakan masalah waris dan hukumnya, tetapi mengesampingkan wasiat beserta hukum yang menyertainya.

2. Memaksakan penghapusan (naskh) ayat-ayat wasiat, khususnya firman Allah: al-wașiyatu li al-wālidayni wa al-aqrabin (wasiat untuk kedua orang tua dan kerabat), berdasarkan hadis ahad yang statusnya terputus (munqathi') diriwayatkan oleh ahl al-Maghāzī, yaitu: là wasiyyata li wärithin (tiada wasiat untuk ahli waris).

3. Mencampuradukkan antara dua konsep yang berbeda, yaitu al-haž (jatah pada warisan) dan al-nașib (bagian pada wasiat), sehingga memunculkan kerancuan pemahaman antara ayat-ayat waris dan ayat-

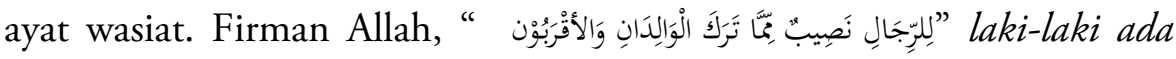
[hak] bagian dari harta peninggalan ibu-bapak dan kerabat-nya, dan bagi perempuan ada [hak] bagi [pula] dari harta peninggalan ibu-bapak dan kerabatnya, baik sedikit atau banyak menurut bagian yang telah ditetapkan. (QS. al-Nisā’ [4]: 7) dipahami sebagai ayat membicarakan masalah waris; padahal ayat ini secara jelas menjelaskan tentang wasiat. 
4. Tidak membedakan antara keadilan universal dalam ayat-ayat waris dan keadilan spesifik dalam ayat-ayat wasiat; padahal ketentuan yang bersifat umum tidak berarti menghapus yang bersifat khusus.

5. Firman Allah, fäin kunna nisä'an fawqa ithnatayni dipahami dengan pengertian: "jika kalian (para perempuan) berjumlah dua atau lebih." Padahal ayat tersebut tidak bisa dipahami dengan pengertian yang tidak masuk akal tersebut.

6. Term 'al-walad' dalam ayat-ayat waris dipahami sebagai anak laki-laki, bahwa hanya anak lelaki-lah yang menjadi sebab terhalangnya dan tertutupnya suatu pewarisan pada pihak lain. Pemahaman semacam ini

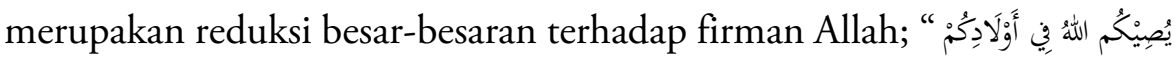
"Allah mensyariatkan bagimu tentang [pembagian pusaka untuk] anak-anakmu. Yaitu bagian seorang anak lelaki sama dengan bagian dua orang anak perempuan," karena dalam ini term alwalad mencakup kedua jenis kelamin baik lelaki maupun perempuan. Di samping itu, pemaknaan reduktif tersebut juga menyalahi salah satu keistimewaan bahasa Arab yang memiliki kosa-kata berbentuk maskulin yang sekaligus mengandung arti feminim. Seperti kata 'abùs (kegentingan), armal (janda/ duda) zawj (pasangan suami-istri), dan walad (anak), karena dalam bahasa Arab tidak dijumpai pemakaian kata 'abūsah, armalah, zawjah dan waladah.

7. Mempertahankan konsep 'awl (menggenapkan prosentase ke atas) dan radd (menggenapkan prosentase ke bawah), dua konsep yang terakhir dari pemaksaan terhadap pemberlakuan empat pola perhitungan ('amaliyyāt al-hisäb al-arba') sehingga mengakibatkan beberapa pihak lain dikurangi haknya secara tidak adil.

8. Para cucu, meskipun yatim, tidak diperbolehkan menerima bagian warisan dari kakek mereka -dalam keadaan mereka sebelumnya telah ditinggal mati bapaknya- meskipun cucu juga tersebut dalam ayat waris.

9. Memberikan bagian tertentu kepada pihak yang sama sekali tidak disebut dalam ayat-ayat waris, seperti paman (dari pihak bapak) dan sebagainya. Penetapan ketentuan ini merupakan akibat dari nalar sosial dan politik patriakhis ${ }^{74}$ masa lalu. ${ }^{75}$

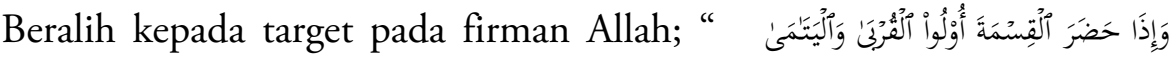

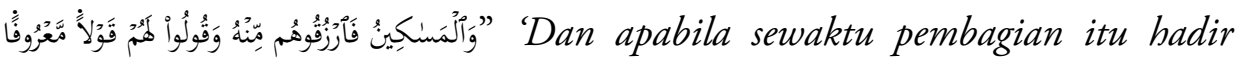
kerabat, anak yatim dan orang miskin, Maka berilah mereka dari harta itu (sekedarnya) dan ucapkanlah kepada mereka Perkataan yang baik' (QS. al-Nisā' 
[4]: 8) akan mendapati tambahan kategori ketiga selain dua kategori dalam surat al-Baqarah, yaitu kategori anak-anak yatim dan kaum miskin. ${ }^{76}$ Shahrūr menjelaskan yang dimaksud kategori ketiga adalah yang memiliki unsur berbeda yang tidak disebut dalam ayat waris, yaitu mereka memiliki bagian (nasib) dalam wasiat namun tidak memiliki bagian jatah (hazz) dalam waris. ${ }^{77}$

Konsep kewarisan Islam secara global menurut Shahrūr, patut diketahui sebelum membahas pemikiran Shahrūr tentang kalālah. Hal ini dikarenakan, konsep Shahrūr ini mempunyai ciri khas tersendiri dalam pembagian harta waris.

Pewarisan menurut Shahrūr adalah proses pemindahan harta yang dimiliki seseorang yang sudah meninggal kepada pihak penerima (warathah) yang jumlah dan ukuran bagian (nasib) yang diterimanya dalam mekanisme wasiat, atau jika tidak ada wasiat, maka penentuan pihak penerima, jumlah dan ukuran bagiannya (hazz) ditentukan dalam mekanisme pembagian warisan. ${ }^{78}$

Shahrūr berpendapat bahwa ayat-ayat tentang waris diturunkan dan diberlakukan bagi seluruh manusia secara kolektif yang hidup di muka bumi, bukan untuk pribadi atau keluarga tertentu. Ayat-ayat waris menggambarkan aturan universal yang ditetapkan berdasarkan aturan matematis (teori himpunan/ teknik analisis/ analisis matematis) dan empat operasional ilmu hitung (penjumlahan, pengurangan, perkalian, dan pembagian). ${ }^{79}$

Dalam hukum waris, Shahrūr simbolkan laki-laki dengan (y) sebagai variabel pengikut dan perempuan dengan simbol (x) sebagai variabel peubah. Dalam hal ini, perempuan adalah dasar dalam penghitungan waris, dan bagian laki-laki ditetapkan batasannya setelah bagian perempuan ditetapkan, karena sebagai variabel pengikut (y) nilainya berubah dan bergerak sesuai dengan perubahan bagian perempuan (x). Oleh karena itu, dalam al-Nisā' ayat 11, jumlah laki-laki hanya disebut sekali dalam ayat, sedangkan jumlah perempuan memiliki kemungkinan nilai yang sangat beragam, sejak dari angka satu hingga tak terbatas. Digambarkan dalam rumus persamaan fungsi: $\mathrm{Y}=\mathrm{f}(\mathrm{x}) .{ }^{80}$

Pembagian warisan menurut Shahrūr, termasuk dalam batas-batas hukum yang telah ditentukan oleh Allah di mana dalam firman-Nya: tilka huudūd Allāh yang berada diawal ayat 13 surat al-Nisā’ setelah Allah menetapkan dan menjelaskan batasan-batasan hukum waris pada ayat 11 dan 12. Adapun batas-batas hukum Allah dalam pembagian warisan, Shahrūr mengelompokkan menjadi tiga batas-batas hukum. ${ }^{81}$

a. Batas Pertama hukum waris; li adh-dhakari mithlu hazzi al-unthayayni. ${ }^{82}$ Batasan ini adalah batas hukum yang membatasi jatah-jatah atau bagianbagian (huzuz) bagi anak-anak si mayit jika mereka terdiri dari seorang 
laki-laki dan dua anak perempuan. Pada saat yang bersamaan ini merupakan kriteria yang dapat diterapkan pada segala kasus, di mana jumlah perempuan dua kali lipat jumlah laki-laki. Jika dipaksakan untuk menerapkan sebuat batasan pada wilayah yang bukan semestinya, maka kita akan tersesat dan terjebak dalam masalah sebenarnya yang sudah diperingatkan oleh Allah untuk menjahuinya sebagaimana firman

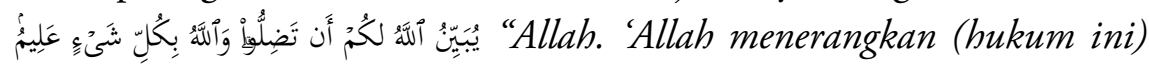
kepadamu, supaya kamu tidak sesat. Dan Allah Maha Mengetahui segala sesuatu." (QS. al-Nisā' [4]: 176). ${ }^{83}$

\begin{tabular}{|c|c|c|}
\hline \multicolumn{1}{|c|}{ Jumlah pewaris } & Jatah bagi laki-laki & Jatah bagi perempuan \\
\hline 1 laki-laki +2 perempuan & $1 / 2$ bagi 1 laki-laki & $1 / 2$ bagi 2 perempuan \\
\hline 2 laki-laki +4 perempuan & $1 / 2$ bagi 2 laki-laki & $1 / 2$ bagi 4 perempuan \\
\hline 3 laki-laki +6 perempuan & $1 / 2$ bagi 3 laki-laki & $1 / 2$ bagi 6 perempuan \\
\hline
\end{tabular}

Pembagian pada kasus ini dapat dirumuskan dengan persamaan:

$\mathrm{F} / \mathrm{M}=2$

F: jumlah perempuan (female)

M: jumlah laki-laki (male)

b. Batas Kedua hukum waris: fä in kunna nisä'an fawqa ithnatayni. ${ }^{84}$

Batas hokum ini membatasi jatah warisan anak-anak jika mereka terdiri dari seorang laki-laki dan tiga perempuan dan selebihnya (3, 4,5 ..dst). Satu laki-laki + perempuan lebih dari dua, maka bagi laki-laki adalah $1 / 3$ dan bagi pihak perempuan adalah $2 / 3$ berapa pun jumlah mereka (di atas dua). Batasan ini berlaku pada seluruh kondisi ketika jumlah perempuan lebih dari dua kali jumlah perempuan.

\begin{tabular}{|c|c|c|}
\hline Jumlah pewaris & Jatah bagi laki-laki & Jatah bagi perempuan \\
\hline 2 laki-laki +5 perempuan & $1 / 3$ bagi 2 laki-laki & $2 / 3$ bagi 5 perempuan \\
\hline 1 laki-laki +7 perempuan & $1 / 3$ bagi 1 laki-laki & $2 / 3$ bagi 7 perempuan \\
\hline
\end{tabular}

Dirumuskan dengan persamaan:

F/M $>2$

F: $\quad$ jumlah perempuan (female)

M: jumlah laki-laki (male)

c. Batas Ketiga hukum waris: wa in kānat wähidatan fa lahä an-nisfu. ${ }^{85}$

Batas hukum ketiga ini membatasi jatah warisan anak-anak dalam kondisi ketika jumlah pihak laki-laki sama dengan jumlah pihak perempuan, dirumuskan dengan persamaan:

$\mathrm{F} / \mathrm{M}<2$ 
F: jumlah perempuan (female)

M: jumlah laki-laki (male)

\begin{tabular}{|c|l|l|}
\hline Jumlah Pewaris & \multicolumn{1}{c|}{ Jatah bagi laki-laki } & \multicolumn{1}{c|}{ Jatah bagi perempuan } \\
\hline 1 laki-laki +1 perempuan & 1/2 bagi 1 laki-laki & 1/2 bagi 1 perempuan \\
\hline 2 laki-laki +2 perempuan & 1/2 bagi 2 laki-laki @ @ 1/4) & 1/2 bagi 2 perempuan (@ 1/4) \\
\hline 3 laki-laki + 3 perempuan & $1 / 2$ bagi 3 laki-laki @ 1/6) & 1/2 bagi 3 perempuan (@ 1/6) \\
\hline
\end{tabular}

Tiga hal tersebut di atas adalah tiga batasan hukum yang ditetapkan Allah untuk pembagian harta warisan, dan tidak keluar dari batasan dalam ayatayat waris. Berbagai problem yang membingungkan para ahli fiqh yang menyebabkan mereka terpolarisasi dalam berbagai mazhab fiqih dalam menentukan problematika berikut: pertama, problematika radd dan awl; kedua, problematika superioritas laki-laki dan problem bahwa anak perempuan tidak bisa menjadi hajib (penghalang ahli waris lain dari menerima harta warisan), ketiga, problematika jumlah perempuan di atas dua, keempat, problematika 1/3 sisa harta dan $1 / 2$ sisa harta, hendak diberikan kepada siapa dan ke mana perginya telah teruraikan pada batas-batas hukum di atas. ${ }^{86}$

Shahrūr menyimpulkan bahwa bagi Allah wasiat lebih utama dan lebih penting daripada waris. Permasalahan ini sebagaimana dijelaskan dalam QS. alMā’idah [5]: 106 menjelaskan perintah wasiat yang diwajibkan bagi orangorang beriman dalam kondisi apapun, baik ketika berdiam maupun bepergian. ${ }^{87}$

\section{Penafsiran Munawir Sjadzali}

Munawir Sjadzali berpandangan bahwa di hampir seluruh Dunia Islam, termasuk di Indonesia, sampai saat ini sistem waris yang diberlakukan oleh umat Islam ataupun negara-negara Islam yang telah mengupayakan kodifikasi hukum lewat perundang-undangan masih tetap menganut asas pembagian waris 2:1. Maksudnya, kaum laki-laki (terutama ayah, suami dan anak laki-laki) mendapatkan dua bagian; sementara kaum perempuan (terutama ibu, istri dan anak perempuan) mendapatkan satu bagian atau separuh dari bagian. Cara seperti ini didukung secara langsung teks ayat QS. al-Nisā' [4]: 11 tanpa dapat ditafsirkan lain karena teks suci dianggap telah jelas (qațî̀).

Walaupun demikian, bagi Sjadzali konsep tersebut untuk saat sekarang masih sangat meragukan keadilannya. Berdasarkan penelitian dan kenyataan yang terjadi dalam masyarakat, laporan para hakim di berbagai daerah yang kuat keislamannya seperti di Sulawesi Selatan dan Kalimantan Selatan didapatkan tindakan masyarakat menyimpang terhadap ketentuan al-Qur'an tentang bagian 2:1. Dalam praktek di masyarakat, para ahli waris tetap meminta fatwa tentang 
ketetapan hukum waris sesuai dengan faraidh Islam yang di dalamnya menetapkan kalkulasi laki-laki dan perempuan 2:1, tetapi dalam prakteknya kerap kali para ahli waris tidak melaksanakan fatwa ketetapan hakim pengadilan agama dengan pembagian 1:1 antara anak-laki-laki dan anak perempuan. Cara seperti itu bukan hanya dilakukan oleh orang-orang awam saja tetapi juga dilakukan oleh tokoh-tokoh organisasi yang cukup menguasai ilmu-ilmu keislaman. ${ }^{88}$

Demikian juga membudayanya penyimpangan kalkulasi 2:1 secara tidak langsung. Banyak kepala keluarga mengambil kebijakan pre-emptive di mana semasa hidup mereka telah membagikan harta kekayaan kepada anak-anak mereka bagian sama rata tanpa membedakan jenis kelamin mereka, sehingga ketika mereka meninggal, harta hanya sedikit sekali atau tidak ada sama sekali kecuali untuk keperluan menyelenggarakan jenazah dan sedikit hal lain. Cara ini walaupun secara langsung tidak bertentangan dengan kalkulasi 2:1 tetapi semangatnya telah dilumpuhkan, permainan bìlah. ${ }^{89}$

Selanjutnya Sjadzali mengungkapkan tentang pengalaman pribadinya kepada seorang ulama terkemuka dalam nasihat waris bagi tiga orang anak lakilaki dan tiga orang anak perempuannya. Tiga orang anak laki-laki tersebut telah banyak menghabiskan harta karena mereka menyelesaikan studi mereka ke luar negeri, sedangkan anak-anak perempuannya tidak meneruskan ke perguruan tinggi kecuali belajar di sekolah-sekolah kejuruan dengan biaya yang jauh lebih murah. Bagi Munawir jika ia meninggal dunia maka menurut ketentuan yang ada, anakanak lelaki akan memperoleh bagian dua kali lipat dari bagian anakanaknya yang perempuan, padahal anak-anak lelakinya telah banyak menghabiskan harta bila dibanding anak perempuan. Di sini keadilan terganggu, jika anak-anak perempuan akan memperoleh bagian waris lebih kecil dari bagian anak laki-laki. ${ }^{90}$

Ulama terkemuka tersebut, menurut Sjadzali ternyata hanya memberitahukan bahwa apa yang beliau lakukan sendiri dan para ulama lainnya dilakukan di mana selagi hidup, mereka telah menghibahkan harta mereka kepada anak-anak mereka tanpa membedakan jenis kelamin dengan pembagian sama rata di antara mereka. Apabila mereka meninggal, harta mereka yang tertinggal sedikit akan dibagi secara faraidh Islam. ${ }^{91}$

Dalam hal ini lebih jauh Sjadzali berkesimpulan:

"Bahwa dalam pembagian warisan anak laki-laki mendapatkan dua kali lebih banyak dari anak perempuan itu tidak lagi mencerminkan semangat keadilan untuk masyarakat kita sekarang ini, dapat di lihat antara lain dari banyaknya penyimpangan dari ketentuan tersebut, tidak 
saja oleh anggota masyarakat Islam yang awam dalam ilmu agama, tetapi oleh banyak ulama”. ${ }^{92}$

Dari pernyataan di atas, Sjadzali menganggap bahwa fikih yang meletakkan pembagian warisan anak laki-laki mendapatkan dua kali lebih banyak dari anak perempuan untuk sekarang ini tidak mencerminkan keadilan. Untuk itu ia menawarkan pembagian warisan antara anak laki-laki dan perempuan adalah sebanding 1:1.

Untuk lebih mempertegas argumennya, Sjadzali berpendapat bahwa dalam memahami QS. al-Nisā' [4]: 17693 yang menyatakan bahwa anak lakilaki mendapatkan bagian dua kali lebih besar dari yang diterima oleh anak perempuan, itu dikaitkan dengan QS. al-Nahl [16] : 90 yang berbunyi:

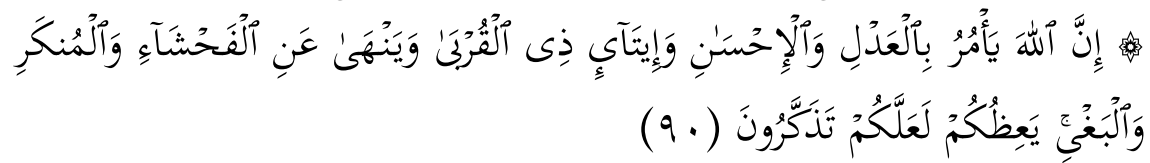

Sesungguhnya Allah menyuruh (kamu) Berlaku adil dan berbuat kebajikan, memberi kepada kaum kerabat, dan Allah melarang dari perbuatan keji, kemungkaran dan permusuban. Dia memberi pengajaran kepadamu agar kamu dapat mengambil pelajaran.

Untuk menilai apakah suatu ketentuan hukum itu sesuai dengan semangat keadilan di tengah masyarakat di mana hukum itu akan diberlakukan diharapkan agar memanfaatkan akal atau nalar kita. ${ }^{94}$ Dengan mengaitkan QS. al-Nisā' [4]: 176 dengan QS. al-Nahl [16]: 90 di atas, maka akan terlahir suatu pemahaman bahwa suatu ketentuan hukum itu harus sesuai dengan rasa dan semangat keadilan di tengah masyarakat, dimana hukum itu akan diberlakukan.

Argumen keadilan itulah yang sebenarnya diusung oleh Sjadzali. Baginya, memungkinkan bisa menerima ketentuan al-Qur'an yang mengatakan bahwa laki-laki mendapat bagian dua kali lipat lebih besar daripada perempuan dalam pembagian warisan, jika memang ketentuan itu membawa implikasi tanggungjawab penuh (untuk membayar mas kawin atau mahar, nafkah dan perumahan) dari pihak laki-laki sebagai suami.

Dalam pandangan Sjadzali, tradisi mahar di Indonesia sekarang ini tinggal formalitas semata. Selain itu, suami dan isteri sama-sama mencari nafkah untuk memenuhi kebutuhan hidup keluarganya. Dengan demikian, maka hubungan antara suami dan isteri tidak lagi merupakan hubungan antara yang memberi dan yang menerima, akan tetapi hubungan dua anak manusia yang sepakat untuk hidup bersama dan membina keluarga atas dasar gotong-royong, masing-masing bekerja mencari nafkah untuk tegaknya rumah tangga. Atas 
dasar pengamatan empiris ini, Sjadzali berpendapat bahwa pembagian laki-laki dua kali lipat dari perempuan tidak relevan lagi. ${ }^{95}$

Pernyataan Sjadzali yang menilai ketentuan waris Islam sekarang ini tidak mencerminkan keadilan dan kemungkinan pergeseran hukum dari ketentuan yang qath'i tersebut mendapat tanggapan yang pro dan kontra. Bagi yang kontra melihat bahwa ayat tentang kewarisan adalah bersifat qath'i dan sudah mencerminkan nilai keadilan bagi umat Islam.

Menurut Munawir Sjadzali, al-Qur'an dan al-Sunnah adalah sesuatu yang perlu adanya konfirmasi karena hal ini memberikan lapangan pengembangan dalam mengimplementasikan nilai-nilai yang terkandung dalam Islam. ${ }^{96}$ Ketentuan al-Qur'an yang dikategorikan sharih yang mengatur bahwa bagian laki-laki itu dua kali lipat dari bagian perempuan adalah QS. al-Nisā' [4]: bagian awal ayat 11 .

Di sinilah letak alasan gagasan dari Munawir Sjadzali untuk memberikan bagian yang sama kepada ahli waris laki-laki dan perempuan, menurut beliau sebelum masa Islam wanita sama sekali tidak mendapatkan bagian warisan. Setelah Islam datang, wanita diberi bagian warisan walaupun hanya setengah dari bagian laki-laki. Ini berarti secara sadar Islam hendak meningkatkan hak dan derajat wanita. Kenapa tidak sekaligus saja wanita diberi bagian yang sama dengan laki-laki memang tidak jelas, tetapi ajaran Islam itu memang sering diberlakukan secara bertahap (ingat penetapan pengharaman khamr). Karena itu dapat dipahami bahwa jiwa dari ayat waris tersebut diatas pada dasarnya usaha meningkatkan hak dab derajat wanita yang harus terus menerus dilakukan dan tidak boleh terhenti. Kemudian oleh karena kehidupan modern sekarang ini telah memberikan kewajiban yang lebih besar kepada wanita dibanding pada masa lalu sehingga wanita kini juga dapat memberikan peran yang sama dengan laki-laki dalam masyarakat, maka logis saja kalau hakhaknya dalam warisan juga ditingkatkan agar sama dengan laki-laki. ${ }^{97}$

Sebagaimana telah disinggung dimuka arti penting reaktualisasi ajaran Islam yang digagas oleh Munawir Sjadzali terletak pada penafsirannya tentang masalah kewarisan. Pembahasan masalah ini terangkai dalam uraian panjangnya mengenai status dan kedudukan perempuan. Dalam pandangan Munawir Sjadzali $^{98}$ Islam sebenarnya mengajarkan prinsip persamaan antara sesama manusia, tanpa ada perbedaan derajat atau tingkat yang didasarkan atas kebangsaan, kesukuan, dan keturunan (mengacu pada QS. al-Hujurāt ayat 13).

Di samping itu juga membudayanya penyimpangan kalkulasi 2:1 secara tidak langsung. Banyak kepala keluarga mengambil kebijakan-kebijakan preemptive di mana semasa hidup mereka telah membagikan harta kekayaan 
mereka kepada anak-anak mereka bagian yang sama rata tanpa membedakan jenis kelamin mereka sehingga ketika mereka meninggal, harta hanya sedikit sekali atau tidak ada sama sekali kecuali untuk penyelenggaraan jenazah dan sedikit hal lain. Cara ini walaupun secara langsung tidak bertentangan dengan kalkulasi 2:1 tetapi semangatnya telah dilumpuhkan, permainan helah dalam agama.

Dari kenyataan tersebut, secara ide, masyarakat muslim menerima konsep waris antara laki-laki dan perempuan 2:1 tetapi dalam prakteknya masyarakat menjalankan sistem pembagian 1:1 antara laki-laki dan perempuan. Masyarakat muslim sendiri tanpa disadari telah melakukan suatu dekonstruksi sistem kalkulasi 2:1 menjadi 1:1, maka bagi Munawir Sjadzali persoalan tersebut harus dipikirkan dalam yurisdiksi Pengadilan Agama, tanpa harus sembunyi-sembunyi dengan melakukan helah hibah atau cara lain, tetapi harus berdasarkan hukum yang didukung oleh penafsiran baru dalam al-Qur'an. ${ }^{99}$

Disadari atau tidak sebenarnya jika sistem kalkulasi 1:1 diterapkan antara laki-laki dan perempuan (apakah nantinya didukung adanya interpretasi baru dan representative), ada beberapa masalah dalam penerapan, sebagai berikut:

a. Mengenai sistem Hijab dan Mahjub ahli waris, apakah diterapkan dalam sistem versi sunni ataukah syi'ah atau lagi hazairin.

b. Sistem kalkulasi 1:1 apakah juga diterapkan terhadap pembagian antara bagian ayah dan ibu adalah sama, bagaimana juga terhadap nenek dan kakek terhadap saudara kandung, lelaki dengan perempuan, dan para saudara lainnya yang seayah dan yang seibu, anak turun anak-anak pewaris, antara mereka dan kelelakian dan kewanitaan dalam penderajatan, seterusnya dalam kondisikondisi lain yang dianggap bermasalah dikalangan fukaha klasik.

c. Apabila diterapkan hanya kepada anak-anak pewaris saja, mengapa tidak terhadap anak turun mereka dan para ahli waris lain, baik dalam pengertian clan-garis genetic ataupun dalam pemahaman jenis kelamin.

d. Kemungkinan lain terjadi yakni menggunakan sistem KUH Perdata, dimana jenis kelamin antara laki-laki dan perempuan adalah sama, tanpa suatu perbedaan, perbedaan hanya terjadi dalam penarika garis keutamaan para ahli waris dimana garis genetik (nasabiyah) ke bawah lebih tinggi derajatnya dari garis ke atas dan menyamping. Konskuensinya sistem paroan tetap terjadi dalam garis manapun.

e. Dalam sistem kewarisan manapun juga, model keadilan tidak hanya ditentukan dalam porsi sama rata antara jenis kelamin, sifat keadilan 
beragam, terutama ketika dalam kondisi berbedanya genetik, harta mungkin dipecahkan atau tetap dalam suatu kebulatan perhitungan dengan sistem pembagian individual. Mungkin keadilan 1:1 dapat diterapkan terhadap anak-anak langsung pewaris atau antara ayah dan ibu, tetapi bagaimana ketika ahli waris terdiri dari adanya anak-anak para cucu dalam garis pancar yeng berbeda? Atau antara dua orang saudara kandung dengan saudara-saudara seibu, dan seterusnya. ${ }^{100}$

Penulis menilai bahwa Munawir Sjadzali benar-benar gemilang ia telah menawarkan tesis baru yang diwarnai dengan model penafsiran "bumi" di mana disadari atau tidak, ia telah menghembuskan penafsiran sosiologis cultural dalam setting lokal masyarakat hanya saja ketika situasi lain terjadi, dimana ahli waris bukan saja hanya anak-anak tetapi di dalamnya ada istri dan suami, ayah dan ibu disamping para cucu dan para saudara, sistem tersebut menemui jalan buntu tanpa ada standar lain untuk memecahkannya. Dengan demikian, tanpa harus menolaknya secara membabi buta, suatu penafsiran boleh jadi terjadi beberapa kekeliruan, dan mengharuskan orang-orang yang terbuka hatinya untuk lebih jauh memikirkannya, setidaknya ada beberapa celah moril yang ditekankan sebagai latarbelakang deskripsi Sjadzali, antara lain;

a. Kebutuhan keadilan bukan hanya hak teks suci secara tersurat, tetapi ada sisi lain yang mengharuskan orang untuk menyelesaikannya secara mandiri.

b. Efektifitas hukum terjadi karena adanya perpaduan nilai-nilai keadilan yang bersifat substantif antara pesan hukum (teks suci atau apa saja) dengan masyarakat sebagai orang-orang yang secara langsung dibebani hukum (mukallaf).

c. Apabila terapi (a) dan (b) tidak diterapkan, akan terjadi kemungkinan respons masyarakat;

1. Mengingkari seluruh peraturan yang dibuat (segala pesan hukum bukan hanya terbatas dalam bidang itu saja tetapi juga di bidang lain) secara langsung, mengabaikannya; seperti meminta fatwa waris ke Pengadilan Umum.

2. Mentaatinya secara doktriner karena adanya ikatan-ikatan tertentu yang mengharuskan untuk tetap tunduk dalam peraturan tersebut (seperti aturan agama, hukum waris dianggap suci, mengingkarinya berarti mengingkari agama).

3. Mengakui atau mentaatinya secara formil, dan mengingkari nya secara tidak langsung dalam etika moril yang didukung kemungkinannya lewat peraturan lain seperti yang terjadi tentang hibah 
kepada anak-anak 1:1 harta miliknya sehingga ketika ia meninggal hartanya hanya sedikit atau tidak ada sama sekali untuk dibagi.

d. Nilai-nilai sosial kultural dapat diperhitungkan dalam sistem kewarisan dan jika mungkin diterapkan sesuai dengan atau dalam konteksnya.

Ketika ada seseorang meninggal dunia, maka perhatian orang-orang (ahli waris) akan tertuju kepada harta warisan yang ditinggalkan. Masalah harta pusaka biasanya menjadi sumber sengketa dalam keluarga, terutama apabila menentukan siapa yang berhak dan siapa yang tidak berhak. Setelah itu, apabila berhak, seberapa banyak hak itu. Hal ini menimbulkan perselisihan dan akhirnya menimbulkan keretakan kekeluargaan. Orang ingin berlaku seadiladilnya, oleh yang lain dianggap tidak adil. ${ }^{101}$

\section{Persamaan dan Perbedaan}

Dari pemaparan penafsiran dan pandangan tentang wasiat atau waris di atas, penulis memahami antara Shahrūr dan Sjadzali ketika menafsirkan ayatayat, mereka melalui metode hermeneutika, menurut mereka sangat bermanfaat untuk melapisi reinterpretasi, rekontruksi, baik reaktualisasi hukum Islam dengan memahami ayat-ayat al-Qur'an. Menurut Shahrūr, problem sosial politik adalah bahwa tradisi patriarkhis dan politik sangat berpengaruh pada penafsiran konvesional. Dengan demikian, wanita hampir selalu merupakan pihak yang diperlakukan secara kurang adil, seperti pembagian waris. ${ }^{102}$ Begitu juga menurut Sjadzali, kalau penafsiran al-Qur'an dilakukan secara menyeluruh, dalam arti bahwa penafsiran yang dilakukan senantiasa mengaitkan antara ayat yang satu dengan ayat yang Iain, kiranya masalah di atas dapat di atasi. QS. alNisā' [4]: 176 yang secara eksplisit mengatakan bahwa anak laki-laki mendapat bagian dua kali lebih besar dari anak perempuan, apabila dikaitkan dengan QS. al-Nahl [16]: 90 yang berisi perintah untuk berbuat adil dan kebajikan, maka akan terlahir satu pemahaman bahwa suatu ketentuan hukum itu harus sesuai dengan rasa dan semangat keadilan di tengah masyarakat, di mana hukum itu akan diberlakukan. ${ }^{103}$ Dalam konteks inilah secara implisit Sjadzali mengusulkan pembagian harta waris di Indonesia dengan ketentuan sama (satu banding satu) bagi anak laki-laki dan anak perempuan.

Perbedaannya dalam pandangan waris adalah, Shahrūr ketika menafsirkan ayat-ayat waris dengan menerapkan ilmu eksakta modern, yakni matematika analitik, teknik analitik, dan teori himpunan. ${ }^{104}$ Sedangkan Sjadzali menjelaskan tentang retorika kewarisan ia mencoba belajar dari keberanian „Umar Ibn al-Khațāāb ketika berijtihad dan menerapkan hukum. Langkah dan 
keberanian 'Umar inilah yang dijadikan model, ukuran, dan pedoman dalam upaya mengedapankan rüh al-tashrì' atau jiwa syari'at Islam daripada formalisme teks al-Qur'an dan hadis. Di samping masalah kewarisan, Sjadzali juga menyinggung sejumlah kasus "bermasalah" lain, yaitu kedudukan wanita, bunga bank, dan kedudukan warga nonmuslim. ${ }^{105}$ Akan tetapi, dari semua ayat tentang waris, tidak semua ayat waris ia tafsirkan.

\section{Relevansi Penafsiran Muhammad Shaḥrūr dan Munawir Sjadzali di Indonesia}

Relevansi penafsiran Shahrūr dengan rekontruksinya terhadap konsep waris yang dilakukan oleh Shahrūr dalam kaitannya dengan konteks Indonesia adalah pada 'limit theory/teori batasnya' (nazhariyyah al-hudūd). Teori batasnya terdiri dari batas bawah (al-hadd al-adnä/minimal) dan batas atas (al-hadd a'lä/maksimal). Maksudnya, batas minimum dan maksimum telah ditetapkan al-Qur'an, adapun ijtihad posisinya ada di antara kedua batas minimum dan maksimum tersebut. Contoh, QS. al-Nisā' [4] 11, tentang pembagian warisan. Batas maksimum laki-laki adalah $2 \mathrm{x}$ perempuan, sedangkan batas minimum perempuan adalah 0.5 dari laki-laki. Ijtihad bergerak di antara dua batas maksimum dan minimum tersebut dengan melihat berbagai aspek yang ada. ${ }^{106}$ Dengan mempertimbangkan gagasan yang digagas oleh Shạ̣rūr dalam penyelesaian kewarisan dalam Islam di Indonesia, dimana kualitas pendapatan harta warisan dalam Islam antara pihak laki-laki dan perempuan adalah bisa saja sepadan satu sama lainnya, dengan teori batas maksimal bagi laki-laki dan batas minimal bagi perempuan, dengan memperhatikan asas keadilan berimbang dalam hukum kewarisan itu sendiri, artinya bahwa harus senantiasa terdapat keseimbangan antara hak dan kewajiban yang harus dilaksanakannya, hal inilah yang menjadi tanggungjawab Peradilan dan Hakimnya sebagai penyelesaian dengan meperhatikan sosio-kultur masyarakat.

Begitu juga pendapat Munawir Sjadzali menyatakan bahwa seiring dengan tumbuhnya kesadaran dan semangat untuk kembali pada agama di kalangan masyarakat Indonesia, terdapat satu fenomena yang cukup memprihatinkan, yakni masih maraknya sikap mendua yang dipraktikkan umat Islam. Hal ini setidaknya terlihat pada sikap dan cara yang mereka tempuh dalam menyelesaikan persoalan keagamaan, khususnya menyangkut kewarisan. Di satu sisi, masyarakat muslim Indonesia masih menganggap "relevan" segala ketentuan hukum tekstual farä 'id yang terdapat dalam al-Qur'an, namun di sisi lain, mereka justru meminta dan menjalankan fatwa baru yang dianggap "lebih adil” dalam hal pembagian waris. Atau jika langkah itu tidak ditempuh, maka 
mereka akan melakukan tindakan pre-emptive, yakni membagi harta peninggalan (warisan) keluarga dengan model hibah sebelum orang tua (pewaris) meninggal. ${ }^{107}$

\section{Kesimpulan}

Pembahasan dalam tulisan ini menyimpulkan beberapa poin. Pertama, tentang penafsiran Muhammad Shahrūr terhadap ayat-ayat waris. Penjelasan yang diuraikan dalam ayat waris tersebut meliputi pembagian waris bagi anakanak ke bawah (al-furū', maḥma nazalū), orang tua ke atas (al-usūl maḥma 'alau), suami istri, saudara, maupun perihal orang mati punah (al-kalālah), yaitu tidak meninggalkan al-furū'dan al-ușül. Dengan demikian, menurutnya, pihakpihak yang tidak disebut dalam ayat-ayat waris di atas, seperti paman, anak lakilaki paman dan seterusnya, adalah pihak-pihak yang sama sekali tidak berhak memperoleh bagian apapun dari harta warisan. Terhadap ayat-ayat tersebut Shahrūr memahami dan mengaplikasikannya dengan cara yang berbeda dengan pendapat dan konsep yang selama ini berlaku baik pada aspek dasar ilmu pengetahuan yang digunakan, seperti terlihat pada 'empat pola perhitungan klasik' (al-amalìyāt al-arba' fì al-hisāb) maupun pada aspek sosial, seperti konsep patrilinialisme dalam masyarakat dan semangat kekeluargaan dan kesukuan yang menjadi patokan pembagian harta warisan pada abad lalu ataupun pada aspek politik, seperti tumpangtindihnya konsep hukum waris yang mencampuradukkan antara kepemilikan, hukum dan otoritas kenabian, sebagai produk hukum pada masa masa Banī Umayyah, Banī Zubair, Banī Abbasiyah, ataupun Banī Tālibiyah.

Kedua, konsep pembagian waris Munawir Sjadzali merupakan diskursus untuk menggali pesan-pesan literalis-kewahyuan yang mempunyai kekayaan makna sebagai bentuk reaktualisasi bagi peran manusia. Bagi Sjadzali hal ini mendapatkan justifikasi al-Qur'an, maka dari itu, untuk mendasari kerja kemanusiaan tersebut membutuhkan medium ijtihad intelektual. Ijtihad ditempatkan pada ikhtiar continuitas untuk mendapatkan hasil komprehensif. Pada sisi lain, kajian pemikiran konsep pembagian waris merupakan diskursus yang selalu menuntut pemahaman atas fundamental values, bagi terciptanya pembaharuan hukum Islam. Sjadzali mecoba memahami nilai normatif terhadap implementasi waris di Indonesia pada aspek kenyataan sosial masyarakat. Dalam hal ini, Sjadzali mengembangkan konsep waris yang terdapat dalam al-Qur'an, untuk mencari relevansi ajaran Islam dengan perkembangan zaman, khususnya dalam konteks Indonesia Modern. Mengingat al-Qur'an bersifat multi-dimensional, sebagai hüdan li al-nās, konsep hukum 
waris Sjadzali, memiliki nilai tersendiri yaitu dengan mengajarkan prinsip persamaan sebagaima pembagian laki-laki dua kali lipat lebih besar dari perempuan tidak lagi relevan. Namun demikian Sjadzali kelihatannya tidak menjelaskan pembagian waris yang memiliki garis ke atas secara memadai. Hal ini karena Sjadzali hanya melihat dari sisi historisitas kedaearahan sebagai wujud kelahiran konsep pembagian waris 1:1 miliknya, tanpa memperhatikan aspek lainnya seperti Ahli Waris dan Pewaris.

Ketiga, relevansi pemikiran Shahrūr dalam konteks kewarisan di Indonesia adalah pada 'teori batasnya'. Dari sini ada relevansi yang cukup jelas antara teori batas yang digagas oleh Shahrūr dan upaya pembaharuan hukum Islam yang diharapkan tumbuh berkembang berkeadilan, dan mampu menjawab kebutuhan masyarakat. Dengan mempertimbangkan gagasan yang digagas oleh Shahrūr dalam penyelesaian kewarisan dalam Islam di Indonesia, dimana kualitas pendapatan harta warisan dalam Islam antara pihak laki-laki dan perempuan adalah bisa saja sepadan satu sama lainnya, dengan teori batas maksimal bagi laki-laki dan batas minimal bagi perempuan, dengan memperhatikan asas keadilan berimbang dalam hukum kewarisan itu sendiri, artinya bahwa harus senantiasa terdapat keseimbangan antara hak dan kewajiban yang harus dilaksanakannya, hal inilah yang menjadi tanggungjawab Peradilan dan Hakimnya sebagai penyelesaian dengan meperhatikan sosiokultur masyarakat. Sedangkan Munawir Sjadzali menyatakan bahwa seiring dengan tumbuhnya kesadaran dan semangat untuk kembali pada agama di kalangan masyarakat Indonesia, terdapat satu fenomena yang cukup memprihatinkan, yakni masih maraknya sikap mendua yang dipraktikkan umat Islam. Hal ini setidaknya terlihat pada sikap dan cara yang mereka tempuh dalam menyelesaikan persoalan keagamaan, khususnya menyangkut kewarisan. Di satu sisi, masyarakat muslim Indonesia masih menganggap "relevan" segala ketentuan hukum tekstual farä’id yang terdapat dalam al-Qur'an, namun di sisi lain, mereka justru meminta dan menjalankan fatwa baru yang dianggap "lebih adil” dalam hal pembagian waris. Atau jika langkah itu tidak ditempuh, maka mereka akan melakukan tindakan pre-emptive, yakni membagi harta peninggalan (warisan) keluarga dengan model hibah sebelum orang tua (pewaris) meninggal.

\section{Catatan Akhir}

${ }^{1}$ Muhammad 'Alī al-Ṣābūnī, Pembagian Waris Menurut Islam, terj. A.M. Basalamah (Jakarta: Gema Insani Press, 1995), h. 33. 
${ }^{2}$ Ahmad Rafiq, Hukum Islam di Indonesia (Jakarta: PT RajaGrafindo Persada, 2000), h. 355 .

${ }^{3}$ Wiryono Projodikoro, Hukum Warisan di Indonesia (Bandung: Sumur, 1983), h. 13.

${ }_{4}^{4}$ Ahmad Rafiq, Fiqh Mawaris (Jakarta: PT RajaGrafindo Persada, 2001), h. 4.

${ }^{5}$ Ahmad Rafiq, Fiqh Mawaris, h. 4.

${ }^{6}$ Asymuni A. Rahman, et al., Ilmu Fiqh 3 (Jakarta: IAIN Jakarta, 1986), Cet. Ke-2, h. 1.

${ }^{7}$ Ali Hasan, Hukum Warisan dalam Islam (Jakarta: Bulan Bintang, t.th), h. 9.

${ }^{8}$ Al-Sayyid Sābiq, Fiqh al-Sunnah (Beirut: Dār al-Fikr, 1983), juz 3, h. 414.

${ }^{9}$ Asep Sugiri, Wasiat Untuk Ahli Waris: Kritik Esktern dan Intern Otentisitas Hadishadis Larangan Wasiat Untuk Abli Waris, Jurnal: al-Jama'ah, Vol. 42, No. 2, 2004/1425 H, h. 468.

${ }^{10}$ David S. Powers, Studies in Qur'an and Hadith: The Formation of the Islamic Law of Inberitance (Bakerley: University of California, 1986), h. 10-12.

${ }^{11}$ Bahkan menurut Ibn Kathīr keputusan ini telah menjadi konsesus (ijmā'), Tafsìr alQur'ān al-'Azim (ttp.: Dār Ihyāa' al-Kutub al-'Arabiyah, t.t.) juz I, h. 11-12.

${ }^{12}$ QS. al-Nisā' [4]: 12

${ }^{13}$ Asep Sugiri, Wasiat Untuk Abli Waris, h. 469.

${ }_{14}$ Abdurrahman, Kompilasi Hukum Islam di Indonesia (Jakarta: Radar Jaya Offset, 2007), h. 108.

${ }^{15}$ Fathurrahman, Ilmu Waris (Bandung: Al-Ma'arif, 1984), h. 35.

${ }^{16}$ Fathurrahman, Ilmu Waris, h. 35.

${ }^{17}$ Muhammad Shahrūr, Metodologi Fiqh Islam Kontemporer, terj. Sahiron Syamsudin dan Burhanudin (Yogyakarta: eLSAQ Press, 2004), h. xiv.

${ }^{18}$ Sulthan Syahril, "Munawir Syadzali (Sejarah Pemikiran Dan Kontribusinya Bagi Perkembangan Pemikiran Islam Indonesia Kontemporer)", Analisis, Vol. XI, Nomor 2, Desember 2011), h. 220.

${ }^{19}$ QS. al-Nisā' [4]: 13.

${ }^{20}$ QS. al-Nisā' [4]: 14.

${ }^{21}$ Muhammad Shahrūr, Metodologi Fiqh Islam Kontemporer, h. 10.

${ }^{22}$ Munawir Sjadzali, Ijtihad Kemanusiaan (Jakarta: Paramadina, 1997), h. 62.

${ }^{23}$ Muhammad Shahrūr, Metodologi Figh Islam Kontemporer,h. 19.

${ }^{24}$ Syamsul Hadi, "Makalah Hermeneutika Mohammad Shahrur: Jurusan Tarbiyah Pendidikan Bahasa Arab STAIN Pamekasan", artikel ini diakses pada tanggal 10 Mei 2014 dari http://googleweblight.com/?lite url=http://hadirukiyah.blogspot.com/2009/06/hermeneutikamohammad-sharur.html?m\%3D1\&ei=STj-7_lg\&lc=idID\&s=1\&m=856\&ts=1434910843\&sig=AG8UcuknTZRIaTvcaikuJTDcmMKTwFhb1g

${ }^{25}$ Muhammad Shahrūr, Metodologi Fiqh Islam Kontemporer, h. 19.

${ }^{26}$ M. Aunul Abied Shah (et al), Islam Garda Depan: Mosaik Pemikiran Islam Timur Tengah (Bandung: Mizan, Cet.I, 2000), h. 237.

${ }^{27}$ M. Aunul Abied Shah (et al), Islam Garda Depan, h. 238. 
${ }^{28}$ Muhammad Shahrūr, Prinsip Dasar Hermeneutika al-Qur'an Kontemporer, terj. Sahiron Syamsuddin dan Burhanuddin (Yogyakarta: eLSAQ Press, 2007), h. 60 .

${ }^{29}$ Muhammad Shahrūr, Prinsip Dasar Hermeneutika al-Qur'an Kontemporer, h. 60.

${ }^{30}$ Muhyar Fanani, Membumikan Hukum Langit; Nasionalisasi Hukum Islam dan Islamisasi Hukum Nasional Pasca Reformasi (Yogyakarta: Tiara Wacana, 2008), h. 204.

${ }^{31}$ Walaupun dibesarkan dalam tradisi madhab sunni terutama al-Shāfíī, pada masamasa berikutnya secara khusus Sjadzali mempelajari pemikiran Abū Hanifah. Lihat M. Dawam Rahardjo, "Kecendekiawanan dan Masalah Legitimasi Politik di Indonesia" dalam Muhammad Wahyuni Nafis dkk. (ed.), Kontekstualisasi Ajaran Islam (Jakarta: IPHI dan Paramadina, 1995), h. 12 .

32 Lihat Munawir Sjadzali, “Dari Lembah Kemiskinan” dalam Muhammad Wahyuni Nafis dkk. (ed.), Kontekstualisasi Ajaran Islam, h. 118.

${ }^{33}$ Hasbullah Mursyid, "Menelusuri Faktor Sosial yang Mungkin Berpengaruh" dalam Muhammad Wahyuni Nafis dkk. (ed.), Kontekstualisasi ...., h. 188. Clifford Geertz dalam penelitiannya tentang kebudayaan Jawa yang dilakukannya di kota kecil Pare (Mojokuto), Jawa Timur pada tahun 1960-an, membagi tiga varian budaya Jawa, yaitu: Priyayi, Santri, dan Abangan. Sub-varian Priyayi terdiri dari para keturunan bangsawan dan pegawai pemerintah yang banyak dipengaruhi oleh ajaran Hindu-Budha dan pandangan dunia mistik Jawa. Subvarian Abangan dominan di kalangan kaum tani yang sangat kental dipengaruhi animisme Jawa. Sedangkan sub-varian Santri dominan di kalangan pedagang dan petani kaya yang lebih murni mempertahankan ajaran Islam, tetapi itu pun disertai dengan elemen-elemen yang berkaitan dengan pandangan dunia Jawa. Lihat Clifford Geertz, The religion of Java, terj. Aswab Mahasin, Abangan, Santri, Priyayi dalam Masyaraka Jawa (Jakarta: Pustaka Jaya, 1983). Lihat Bambang Pranowo, "Runtuhnya Dikotomi Santri-Abangan: Refleksi Sosiologis atas Perkembangan Islam di Jawa Pasca 1965”, (Jakarta: Pidato Pengukuhan Guru Besar dalam Ilmu Sosiologi Agama pada Fak. Ushuluddin IAIN Syarif Hidayatullah Jakarta, 27 Desember 2001)

${ }^{34}$ Bahtiar Effendy, dkk., "Munawir Sjadzali, MA; Pencairan Ketegangan Ideologis" dalam Azyumardi Azra dan Saiful Umam (ed.), Menteri-Menteri Agama RI Biografi Sosial Politik (Jakarta: INIS, PPIM, Balitbang Depag RI, 1998), h. 373.

${ }^{35}$ Mambaul Ulum dikenal sebagai perintis dan pelopor pembaharuan pendidikan Islam Modern karena dipergunakannya sistem pendidikan Barat secara selektif. Didirikan pada tahun 1905 oleh R. Adipati Sosrodiningrat dan Raden Penghulu Tafsirul Anam. Pada mulanya, lembaga pendidikan ini hanya berbentuk pesantren kemudian pada 1916, diadakan pembaruanpembaruan dengan mengadakan kelas-kelas; dari kelas I sampai XI. Tujuan utama didirikannya madrasah ini adalah dijadikan sebagai proyek untuk mencetak para kader ulama dan pejabat keagamaan dengan bidang pokok penguasaan membaca al-Qur'an dan kemampuan pemahaman ilmu fikih. Lihat Mahmud Yunus, Sejarah Pendidikan Islam di Indonesia (Jakarta: Mutiara Sumber Widya, 1985), h. 86.

36 Lihat Munawir Sjadzali, Pendidikan Agama dan Pengembangan Pemikiran Keagamaan (Jakarta: Biro Hukum dan Humas Depag RI, 1985), h. 23. 
${ }^{37}$ Kuswadi, "Mambaul Ulum Kesunanan Surakarta, Sejarah dan Pemikiran” (Tesis Program Pascasarjana IAIN Syarif Hidayatullah Jakarta, 1997), h. 176.

${ }^{38}$ Ensiklopedi Tokoh Indonesia, "Prof. Dr. H. Munawir Sjadzali MA, Diplomat dan Pembaharu Islam”, (Internet: Tokoh Indonesia . Com, 3 November 2004), h. 1.

${ }^{39}$ Bahtiar Effendy, dkk, Menteri-Menteri Agama RI Biografi Sosial Politik, h. 376.

${ }^{40}$ Munawir Sjadzali, Dari Lembah...., h. 23-25.

${ }^{41}$ Munawir Sjadzali, Dari Lembah...., h. 37.

${ }^{42}$ Obituri, Perginya Seorang Pluralis (Jakarta: Majalah Tempo, 1 Agustus 2004), h. 42.

${ }^{43}$ Bahtiar Effendy, dkk., Menteri-Menteri Agama RI Biografi Sosial Politik, h. 380.

${ }^{44}$ Munawir Sjadzali, Dari Lembah..., h. 48.

${ }^{45}$ Bahtiar Effendy dkk., Menteri-Menteri Agama RI Biografi Sosial Politik, h. 383-384.

46 Faisal Ismail, Islam: Idealitas Ilahiyah dan Realitas Insaniyah (Yogyakarta: Adi Wacana [Tiara Wacana Group], 1999), h. 136.

${ }^{47}$ Faisal Ismail, Islam: Idealitas Ilahiyah dan Realitas Insaniyah, h. 139

${ }^{48}$ Dawam Rahardjo, "Kecendekiawanan dan Masalah Legitimasi Politik di Indonesia", dalam Muhamad Wahyuni Nafis dkk. (ed.), Kontekstualisasi Ajaran Islam, h. 394

49 B.J. Boland, The Struggle of Islam in Modern Indonesia ( New York: Martinus Nijhoff, 1971), h. 81.

${ }^{50}$ Mahmud Yunus, Kamus Arab-Indonesia (Jakarta: Hidakarya Agung, 1990), cet. 8, h. 496.

${ }^{51}$ Muhammad 'Alī al-Ṣābunī, Pembagian Waris Menurut Islam, terj. A.M. Basalamah (Jakarta: Gema Insani Press, 1995), h. 33.

52 Moh Rifai, Ilmu Fiqih Islam (Semarang: CV Toha Putra, 1978), h. 512.

53 Ahmad Warson Munawir, Al-Munawir Kamus Arab-Indonesia (Surabaya: Pusat Progresif, 1997), h. 104.

${ }^{54}$ Amir Syarifuddin, Hukum Kewarisan Islam (Jakarta: Prenada Media, 2005), h. 5.

55 http://edon79.wordpress.com/2009/07/10/fiqh-mawaris/, diunduh pada tanggal 22 Januari 2015 pukul 10.30 WIB.

${ }^{56}$ Moh Rifai, Ilmu Fiqih Islam, h. 513.

${ }^{57}$ Imām al-Qurțubī, al-Jāmi' li Aḥkām al-Qur'ān, terj. Fathurrahman, jilid 2 (Jakarta: Pustaka Azzam, 2007), h. 596.

${ }^{58}$ Hadis riwayat al-Bukhārī pada pembahasan tentang Nikah, bab: berwasiat untuk Para Istri (3/257). Diriwayatkan pula oleh Muslim pada pembahasan tentang Susuan, bab: Wasiat untuk Istri (3/1090), dan juga oleh al-Tirmidhī pada pembahasan tentang Tafsir, dan oleh Ibn Mājah pada pembahasan tentang Nikah. Lihat Imām al-Qurṭubī, al-Jāmi' li A ḥkām alQur'àn, jilid 2, h. 596.

${ }^{59}$ Abū Bakr Aḥmad ibn 'Alī al-Rāzī al-Jașṣāṣ, A hloām al-Qur'ān (Beirut: Dār al-Fikr, t.th.), juz I, h. 165. Lihat juga: Ibn Kathīr, Tafsìr Ibn Kathīr (Beirut: Dār al-Fikr, t.th.), jilid I, h. 212.

${ }^{60}$ Al-Jaș̣āṣ, Aḥkām al-Qur'ān, h. 165. 

h. $212-214$.

${ }^{61}$ Ibn Kathīr al-Qurshī al-Dimashqī, Tafsìr Ibn Kathīr (Beirut: Dār al-Fikr, t.th), juz I,

${ }^{62}$ Ibn al-'Arābī, Aḥkàm al-Qur'ān (Beirut: Dār al-Ma'rifah, t.th.), jilid I, h. 69.

${ }^{63}$ Muhammad Abī 'Abdillāh Muhạmmad Ibn Ismā’il ibn Ibrāhīm ibn al-Mughirah ibn Bardā Zabh, Ṣaḥīh al-Bukhārī (Beirut: Dār al-Kutub al-'Ilmiyyah, t.th.), Juz II, h. 204.

${ }^{64}$ Ibn al-'Arābī, Abkām al-Qur'än, h. 69.

${ }^{65}$ M. Rashīd Riḍā, Tafsīr al-Manār (Mesir: Syirqah 'Iqalat al-Dīn, t.th.), juz II, h. 135.

${ }^{66}$ QS. al-Baqarah [2]: 180.

${ }^{67}$ Muhammad Shahrūr, Metodologi Figh Islam Kontemporer, h. 325.

${ }^{68}$ Muhammad Shahrūr, Metodologi Figh Islam Kontemporer, h. 326.

${ }^{69}$ Muhammad Shahrūr, Metodologi Figh Islam Kontemporer, h. 326.

${ }^{70}$ Muhammad Shahrūr, Metodologi Figh Islam Kontemporer, h. 330.

${ }^{71}$ Muhammad Shahrūr, Metodologi Figh Islam Kontemporer, h. 330.

${ }^{72}$ Muhammad Shahrūr, Metodologi Figh Islam Kontemporer, h. 329.

${ }^{73}$ Muhammad Shahrūr, Metodologi Figh Islam Kontemporer, h. 320.

${ }^{74}$ Patriaki adalah sistem sosial yang menempatkan laki-laki sebagai sosok otoritas utama yang sentral dalam sosial organisasi. Kalau dalam keluarga patriarki adalah pengelompokan sosial yang sangat mementingkan garis keturunan bapak. Lihat Tim Redaksi Kamus Besar Indonesia Edisi Ketiga (Jakarta: Balai Pustaka, 2005), h. 837.

${ }^{75}$ Muhammad Shahrūr, Metodologi Fiqh Islam Kontemporer, h. 322.

${ }^{76}$ Muhammad Shahrūr, Metodologi Figh Islam Kontemporer, h. 328.

${ }^{77}$ Mereka bisa terdiri pribadi-pribadi atau sekelompok orang ataupun berupa lembaga nirlaba (yayasan) yang bergerak di bidang amal dan kemanusian, seperti menangani para anak yatim, orang terlantar, orang-orang miskin, orang-orang jompo dan orang-orang cacar. Lihat Muhammad Shahrūr, Metodologi Figh Islam Kontemporer, h. 328.

${ }^{78}$ Muhammad Shahrūr, Metodologi Figh Islam Kontemporer, h. 334.

${ }^{79}$ Muhammad Shahrūr, Metodologi Fiqh Islam Kontemporer, h. 324.

${ }^{80}$ Muhammad Shahrūr, Metodologi Figh Islam Kontemporer, h. 341.

${ }^{81}$ Muhammad Shahrūr, Metodologi Figh Islam Kontemporer, h. 359.

${ }^{82}$ Muhammad Shahrūr, Metodologi Figh Islam Kontemporer, h. 340.

${ }^{83}$ Muhammad Shahrūr, Metodologi Figh Islam Kontemporer, h. 360.

${ }^{84}$ Muhammad Shahrūr, Metodologi Fiqh Islam Kontemporer, h. 340.

${ }^{85}$ Muhammad Shahrūr, Metodologi Fiqh Islam Kontemporer, h. 340.

${ }^{86}$ Muhammad Shahrūr, Metodologi Figh Islam Kontemporer, h. 363.

${ }^{87}$ Muhammad Shahrūr, Metodologi Figh Islam Kontemporer, h. 331.

88 A. Sukris Sarmadi, Transendensi Keadilan Hukum Waris Islam Transformatif (Jakarta: Raja Wali Pers, PT. Grafindo Persada, 1997), h. 267.

${ }^{89}$ Kata ḩilah (حيلة) secara bahasa berarti muslihat, siasat, tipu daya dan mengalihkan. Sedangkan secara istilah berarti berpalingnya seseorang dari sesuatu yang tidak disukainya kepada apa yang disenanginya. Lihat. Abū Husain ibn Zakaria, Maqāyis al-Lughah, (Kairo: Musțafā al-Bābī al-Halabī wa Aulāduhu, 1979), jilid I, cet. Ke-2, h. 21. Lihat juga, 'Alī ibn Muhạmmad al-Sharīf al-Jurjānī, Kitāb al-Ta'rīfät (Beirūt: Maktabah Lubnān, 1995), h. 94. 
Kemunculan hìlah dalam hukum Islam menimbulkan pro dan kontra dari fuqaha'. Imām Mālik, Imām al-Shāfi'i dan Aḥmad Ibn Hạbal menolak ḥilah karena dinilai sebagai bentuk pelecehan terhadap hukum Allah dan bertentangan dengan maslahat yang menjadi tujuan hukum Islam (maqāshid al-syarīeeah). Sementara Abū Hanifah dan sebagian Shāfì̀iyyah membolehkan hïlah tetapi dalam batas tidak dimaksudkan untuk membatalkan hukum syara' secara terang-terangan. Penjelasan lebih lanjut tentang ḩilah, lihat tulisan Azharuddin Lathif "Eksistensi Hīlah dalam Hukum Islam", Ahkam: Syariah-Hukum dan Pranata Sosial, No. 09/IV/2002, h. 31-39.

90 Lihat Munawir Sjadzali, "Reaktualisasi Ajaran Islam", dalam Iqbal Abdurrauf Saimima, Polemik Reaktualisasi Ajaran Islam (Jakarta: Pustaka Panjimas, 1988), h. 2-5

${ }^{91}$ Munawir Sjadzali, "Reaktualisasi Ajaran Islam”, dalam Iqbal Abdurrauf Saimima, Polemik Reaktualisasi Ajaran Islam, h. 5.

${ }^{92}$ Munawir Sjadzali, Ijtihad Kemanusiaan (Jakarta: Paramadina, 1997), h. 7.

${ }^{93}$ QS. al-Nisā’ [4]: 176

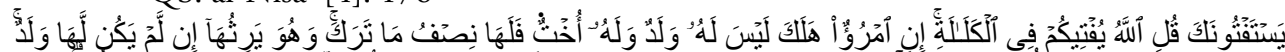

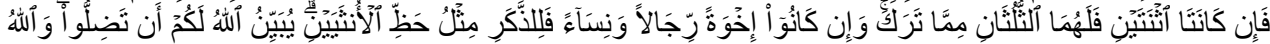

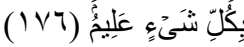

Mereka meminta fatwa kepadamu (tentang kalalah). Katakanlah: "Allah memberi fatwa kepadamu tentang kalalah (yaitu): jika seorang meninggal dunia, dan ia tidak mempunyai anak dan mempunyai saudara perempuan, Maka bagi saudaranya yang perempuan itu seperdua dari harta yang ditinggalkannya, dan saudaranya yang laki-laki mempusakai (seluruh harta saudara perempuan), jika ia tidak mempunyai anak; tetapi jika saudara perempuan itu dua orang, Maka bagi keduanya dua pertiga dari harta yang ditinggalkan oleh yang meninggal. dan jika mereka (ahli waris itu terdiri dari) saudara-saudara laki dan perempuan, Maka bahagian seorang saudara laki-laki sebanyak bahagian dua orang saudara perempuan. Allah menerangkan (hukum ini) kepadamu, supaya kamu tidak sesat. dan Allah Maha mengetahui segala sesuatu.

${ }^{94}$ Munawir Sjadzali, Ijtihad Kemanusiaan, h. 63.

${ }^{95}$ Munawir Sjadzali, Ijtihad Kemanusiaan, h. 62

${ }^{96}$ Munawwir Syadzali, Kontekstualisasi Ajaran Islam, h. 181-184

${ }^{97}$ Munawwir Syadzali, Ijtihad dalam Sorotan (Bandung: Mizan, 1990), h. 23.

98 Mahsun Fuad, Hukum Islam Indonesia; Dari Nalar Partisipatoris Hingga Emansipatoris (Yogyakarta: LKIS, 2005), h. 94.

${ }^{99}$ A. Sukris Sarmadi, Transendensi Keadilan Hukum Waris Islam Transformatif, h. 207.

100 A. Sukris Sarmadi, Transendensi Keadilan Hukum Waris Islam Transformatif, h. 270.

${ }^{101}$ Zakiah Daradjat (et al), Ilmu Fiqih, Jilid 3 (Yogyakarta: Dana Bhakti Wakaf, 1995), h. 4 .

${ }^{102}$ Muhammad Shahrūr, Metodologi Figh Islam Kontemporer, h. 116.

${ }^{103}$ Munawir Sjadzali, Ijtihad, h. 62-63.

${ }^{104}$ Muhammad Shahrūr, Metodologi Figh Islam Kontemporer, h. 116.

${ }^{105}$ Munawir Sjadzali, Ijtihad, h. 58-71.

${ }^{106}$ Amin Abdullah, Neo Ushul Fiqih Menuju Ijtihad Kontekstual (Yogyakarta: Fakultas Syariah Press dan Forum Studi Hukum Islam, 2004), h. 158. 
${ }^{107}$ Munawir Sjadzali, Reaktualisasi ajaran Islam, dalam Iqbal Abdur Rauf Saimia (ed.), Polemik Reaktualisasi Ajaran Islam (Jakarta: Pustaka Panjimas 1988), h. 2. "Dari Lembah Kemiskinan", dalam panitia penulisan buku 70 tahun Munawwir Syadzali, Kontekstualisasi Ajaran Islam (Jakarta: Ikatan Persaudaraan Haji Indonesia (IPHI), 1995), h. 87; Ijtihad Kemanusiaan (Jakarta; Paramadina, 1997), h. 8.

\section{Daftar Pustaka}

Abdurrahman, Kompilasi Hukum Islam di Indonesia, Jakarta: Radar Jaya Offset, 2007.

Abied Shah, M. Aunul. et al; Islam Garda Depan: Mosaik Pemikiran Islam Timur Tengah, Bandung: Mizan, 2000.

al-'Arābī, Ibn. Ahkeàm al-Qur'ān, Beirut: Dār al-Ma'rifah, t.th.

Boland, B.J. The Struggle of Islam in Modern Indonesia, New York: Martinus Nijhoff, 1971.

al-Bukhārī, Muhammad Abī 'Abdillāh Muhammad Ibn Ismā’il ibn Ibrāhīm ibn al-Mughirah ibn Bardā Zabh. Șaḥịh al-Bukhārī, Beirut: Dār al-Kutub al'Ilmiyyah, t.th.

Daradjat, et al., Zakiah. Ilmu Fiqih, Yogyakarta: Dana Bhakti Wakaf, 1995.

Effendy, Bahtiar dkk. "Munawir Sjadzali, MA; Pencairan Ketegangan Ideologis", dalam Azyumardi Azra dan Saiful Umam (ed.), MenteriMenteri Agama RI Biografi Sosial Politik, Jakarta: INIS, PPIM, Balitbang Depag RI, 1998.

Ensiklopedi Tokoh Indonesia, "Prof. Dr. H. Munawir Sjadzali MA, Diplomat dan Pembaharu Islam", Internet: Tokoh Indonesia . Com, 3 November 2004 .

Fuadi, Asral. Tinjauan Hukum Islam terhadap Pemikiran Muhammad Syahrur dalam Redukitas Hukum Wasiat, Yogkarta: Al-Ahwal Asy-Syahshiyyah, 2013.

Fatimah, Putri Ajeng. "Waris Kalālah dalam Pandangan Wahbah al-Zuhailī: Tafsir QS. al-Nisā' [4]: 12 dan 176”, Skripsi: Jurusan Tafsir Hadis Fakultas Ushuluddin UIN Syarif Hidayatullah Jakarta, 2011.

Fatimah, Neneng. "Konsep Waris dalam Perspektif Prof. Dr. H. Munawir Sjadzali, MA”, Skripsi: Pendidikan Agama Islam UIN Syarif Hidayatullah Jakarta, 2012.

Fathurrahman, Ilmu Waris, Bandung: Al-Ma'arif, 1984. 
Fanani, Muhyar. Membumikan Hukum Langit; Nasionalisasi Hukum Islam dan Islamisasi Hukum Nasional Pasca Reformasi, Yogyakarta: Tiara Wacana, 2008.

Fuad, Mahsun. Hukum Islam Indonesia; Dari Nalar Partisipatoris Hingga Emansipatoris, Yogyakarta: LKIS, 2005.

Geertz, Clifford. The religion of Java, terj. Aswab Mahasin, Abangan, Santri, Priyayi dalam Masyaraka Jawa, Jakarta: Pustaka Jaya, 1983.

Hasan, Ali. Hukum Warisan Dalam Islam, Jakarta: Bulan Bintang, t.th.

Ismail, Faisal. Islam: Idealitas Ilahiyah dan Realitas Insaniyah, Yogyakarta: Adi Wacana [Tiara Wacana Group], 1999.

Imadudin, "Implikasi Pendefinisian Makna Kalalah Menurut Ulama Klasik dan Orientalis Terhadap Pembagian Harta Waris", Skripsi: Fakultas Syariah dan Hukum UIN Syarif Hidayatullah Jakarta, 2003.

al-Jașsāṣ, Abū Bakr Aḥmad ibn „Alī al-Rāzī. Aḥkām al-Qur'ān, Beirut: Dār alFikr, t.th.

al-Jurjānī, 'Alī ibn Muhammad al-Sharīf. Kitāb al-Ta’rīfāt, Beirūt: Maktabah Lubnān, 1995.

Kuswadi, "Mambaul Ulum Kesunanan Surakarta, Sejarah dan Pemikiran", (Tesis pada Program Pascasarjana IAIN Syarif Hidayatullah Jakarta, 1997.

Kuzman, Charles (ed). Liberal Islamic; A Souncebook, terj. Wacana Islam Liberal: Pemikiran Islam Kontemporer Tentang Isu-isu Global, oleh. Bahrul Ulum, Jakarta: Paramadina, 2003.

Kathīr al-Qurshī al-Dimashqī, al-Imām Abū Fidā Ismāill Ibn. Tafsīr al-Qur" àn al-Až̀m, Beirut: Dār al-Fikr, t.th.

Kamāl Faqih, Allamah. Tafsìr Nurūl Qur'ān, terj. Rd Hikmat Danaatmaja, Nūr al-Qur'àn: An Enlightening Commentary into the Ligh of the Holy Qur'an, Jakarta: al-Huda, 2003.

Lathif, Azharuddin. "Eksistensi Hīlah dalam Hukum Islam", Abkam: Jurnal Syariah-Hukum dan Pranata Sosial, No. 09/IV/2002.

Mardiono, "Pembagian Harta Waris (Studi Komparatif Penafsiran Surat alNisā’ ayat 11-12 dengan Adat Minangkabau", Skripsi: Jurusan Tafsir Hadis Fakultas Ushuluddin UIN Syarif Hidayatullah Jakarta, 2010.

Munawir, Ahmad Warson. Al-Munawir Kamus Arab-Indonesia, Surabaya: Pusat Progresif, 1997. 
Nasuhi, Hamid, et all. Pedoman Penulisan Karya Ilmiah: Skripsi, Tesis dan Disertasi, Jakarta: CeQda, 2007.

Nafis, Muhammad Wahyuni dkk. Kontekstualisasi Ajaran Islam, Jakarta: IPHI dan Paramadina, 1995.

Powers, David S. Studies in Qur'an and Hadith: The Formation of the Islamic Law of Inberitance, Bakerley: University of California, 1986.

Pranowo, Bambang. "Runtuhnya Dikotomi Santri-Abangan: Refleksi Sosiologis atas Perkembangan Islam di Jawa Pasca 1965”, Jakarta: Pidato Pengukuhan Guru Besar dalam Ilmu Sosiologi Agama pada Fak. Ushuluddin IAIN Syarif Hidayatullah Jakarta, 27 Desember 2001.

Projodikoro, Wiryono. Hukum Warisan di Indonesia, Bandung: Sumur, 1983.

al-Qurțubī, Imām. al-Jāmi' li Aḅkām al-Qur'ān, terj. Fathurrahman, Jakarta: Pustaka Azzam, 2007.

Rafiq, Ahmad. Hukum Islam di Indonesia, Jakarta: PT RajaGrafindo Persada, 2000.

-----. Fiqh Mawaris, Jakarta: PT RajaGrafindo Persada, 2001.

Riḍā, M. Rashīd. Tafsīr al-Manār, Mesir: Syirqah 'Iqalat al-Dīn, t.th.

Rifai, Moh. Ilmu Fiqih Islam, Semarang: CV Toha Putra, 1978.

Rahman, Asymuni A. et al., Ilmu Figh 3, Jakarta: IAIN Jakarta, 1986.

Rahardjo, Dawam. "Kecendekiawanan dan Masalah Legitimasi Politik di Indonesia", dalam Muhamad Wahyuni Nafis dkk. (ed.), Kontekstualisasi Ajaran Islam. Sābiq, Al-Sayyid. Fiqh al-Sunnah, Beirut: Dār al-Fikr, 1983. Sugiri, Asep. "Wasiat Untuk Ahli Waris: Kritik Esktern dan Intern Otentisitas Hadis-hadis Larangan Wasiat Untuk Ahli Waris", Jurnal: al-Jama'ah, Vol. 42, No. 2, 2004/1425 H

Shahrūr, Muhammad. Naḥw Ușūl Jadìdah Li al-Fiqh al-Islāmī, terj. Metodologi

Figh Islam Kontemporer oleh Sahiron Syamsudin dan Burhanudin, Yogyakarta: eLSAQ Press, 2004. -. al-Kitāb wa al-Qur'än; Qirā'ah Mu'ashirah, Damaskus: al-Ahāli, 1990.

--------. Prinsip dan Dasar Hermeneutika al-Qur'an Kontemporer, terj. Burhanuddin dan Sahiron Syamsuddin Yogyakarta: Elsaq Press, 2004.

Syahril, Sulthan. "Munawir Syadzali (Sejarah Pemikiran dan Kontribusinya Bagi Perkembangan Pemikiran Islam Indonesia Kontemporer)", Analisis, Volume XI, Nomor 2, Desember 2011.

Syadzali, Munawir. Ijtihad Dalam Sorotan, Bandung: Mizan, 1990. Ijtihad Kemanusiaan, Jakarta; Paramadina, 1997. 
Reaktualisasi Ajaran Islam, dalam Iqbal Abdur Rauf Saimia (ed.), Polemik Reaktualisasi Ajaran Islam, Jakarta: Pustaka Panjimas 1988.

--------. Kontekstualisasi Ajaran Islam: 70 Tahun Munawwir Sjadzali, Jakarta: Pustaka Panjimas, 1988.

--------. Kontekstualisasi Ajaran Islam, Jakarta: Ikatan Persaudaraan Haji Indonesia (IPHI), 1995,

---.----. "Reaktualisasi Ajaran Islam", dalam Iqbal Abdurrauf Saimima, Polemik Reaktualisasi Ajaran Islam, Jakarta: Pustaka Panjimas, 1988.

--------. Pendidikan Agama dan Pengembangan Pemikiran Keagamaan, Jakarta: Biro Hukum dan Humas Depag RI, 1985. 